\title{
How will a drier climate change carbon sequestration in soils of the deciduous forests of Central Europe?
}

\author{
István Fekete · Imre Berki · Kate Lajtha • Susan Trumbore • Ornella Francioso • \\ Paola Gioacchini · Daniela Montecchio · Gábor Várbíró · Áron Béni · \\ Marianna Makádi · Ibolya Demeter · Balázs Madarász • Katalin Juhos • \\ Zsolt Kotroczó
}

Received: 29 March 2020/ Accepted: 8 November 2020/Published online: 19 November 2020

(C) The Author(s) 2020, corrected publication 2020

\begin{abstract}
Global warming is accompanied by increasing water stress across much of our planet. We studied soil biological processes and changes in soil organic carbon (SOC) storage in 30 Hungarian oak forest sites in the Carpathian Basin along a climatic gradient (mean annual temperature (MAT) 9.6-12.1 ${ }^{\circ} \mathrm{C}$, mean annual precipitation (MAP) $545-725 \mathrm{~mm}$ ) but on similar gently sloped hillsides where the parent materials are loess and weathered dust inputs dating from the end of the ice age. The purpose of this research was to understand how a drying climate, predicted for this region, might regulate long-term SOC sequestration. To examine
\end{abstract}

Responsible Editor: R. Kelman Wieder

I. Fekete $(\square)$

Institute of Environmental Sciences, University of

Nyíregyháza, Nyíregyháza, Hungary

e-mail: feketeistani@gmail.com

I. Fekete $\cdot$ K. Juhos $\cdot$ Z. Kotroczó $(\bowtie)$

Department of Soil Science and Water Management,

Szent István University, Budapest, Hungary

e-mail: kotroczo.zsolt@gmail.com

I. Berki

Institute of Environmental and Earth Sciences, University of Sopron Hungary, Sopron, Hungary

K. Lajtha

Department of Crop and Soil Sciences, Oregon State

University, Corvallis, OR, USA the effects of decreasing water availability, we compared soil parameters and processes in three categories of forest that represented the moisture extremes along our gradient and that were defined using a broken-stick regression model. Soil biological activity was significantly lower in the driest ("dry") forests, which had more than double the SOC concentration in the upper $30 \mathrm{~cm}$ layer $(3.28 \mathrm{~g} \mathrm{C} / 100 \mathrm{~g}$ soil $\pm 0.11 \mathrm{SE})$ compared to soils of the wettest ("humid") forests (1.32 g $\mathrm{C} / 100 \mathrm{~g}$ soil $\pm 0.09 \mathrm{SE}$ ), despite the fact that annual surface litter production in humid forests was $~ 37 \%$ higher than in dry forests. A two-pool SOM model constrained to fit radiocarbon data indicates that turnover times for fast and slow pools are about half as long in the humid soil compared to the dry soil, and humid soils transfer $\mathrm{C}$ twice as efficiently from fast to

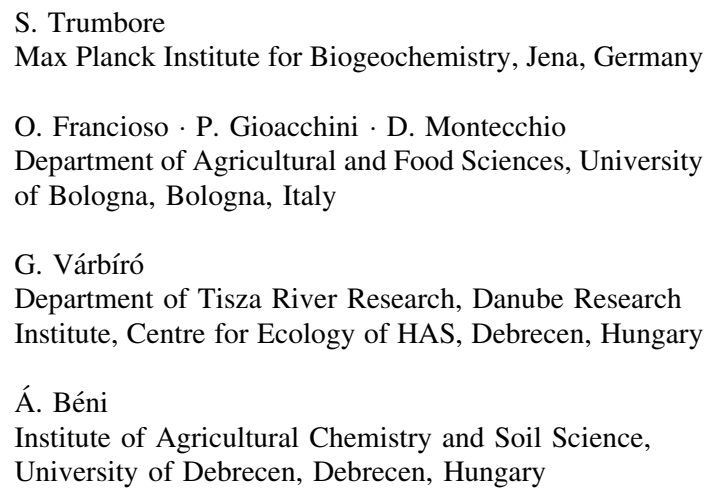


slow pools. Enzyme activity and fungal biomass data also imply shorter turnover times associated with faster degradation processes in the soils of humid forests. Thermogravimetry studies suggest that more chemically recalcitrant compounds are accumulating in the soils of dry forests. Taken together, our results suggest that the predicted climate drying in this region might increase SOC storage in Central European mesic deciduous forests even as litter production decreases.

Keywords SOM $\cdot \mathrm{C}$ sequestration $\cdot$ Soil enzyme activity $\cdot$ Radiocarbon - Climosequence .

Decomposition · Climate change $\cdot$ Forest soil $\cdot$ Soil biology

\section{Introduction}

Forests contain $85-90 \%$ of the global vegetation carbon pool (Schlesinger 1997; Urban et al. 2015; Ma et al. 2017; Sun and Liu 2020) and 45-73\% of the global soil carbon pool (Dixon et al. 1994; McGarvey et al. 2015). Temperate deciduous forests in the northern mid-latitudes play an important role in the global C cycle (Keeling et al. 1996; Barr et al. 2002), and forests of the temperate zone are actively accumulating $\mathrm{C}$ in large enough quantities to affect the global C budget (Canadell et al. 2007). Soils are important components of global $\mathrm{C}$ stores, containing about two and a half times as much $\mathrm{C}$ as is found in vegetation (Batjes 1998; Field and Raupach 2004). Globally $\mathrm{CO}_{2}-\mathrm{C}$ release from soil is estimated to be 9.4-9.8 $\times 10^{16} \mathrm{~g} \mathrm{year}^{-1}$ (Bahn et al. 2010; Oertel et al. 2016), more than 10 times the amount of $\mathrm{C}$

M. Makádi · I. Demeter

Centre for Agricultural Sciences, Research Institute of Nyíregyháza, University of Debrecen, Nyíregyháza, Hungary

B. Madarász

Geographical Institute, Research Centre for Astronomy and Earth Sciences, Budapest, Hungary derived from fossil fuel combustion (Oertel et al. 2016). Although vegetation response to changing climate has been effectively measured and modeled (Mohan et al. 2009; Allen et al. 2016), less is known about how these changes will translate to changes in soil $\mathrm{C}$ in part because soil $\mathrm{C}$ stocks cannot be measured as easily as vegetation biomass over broad geographic scales. The effects of temperature and precipitation on the $\mathrm{C}$ dynamics of forest and forest soils have been reported in numerous studies (e.g. Wei et al. 2010; Balasmeh and Karmaker 2020; Li et al. 2020), but results have been mixed, in part because climate has both direct effects on soil $\mathrm{C}$ balance through effects on biological processes, as well as indirect effects through changes to vegetation, root activity, and litter inputs. Thus, despite its important role in the biosphere and the global environmental system, interactions among physical, chemical and biological processes regulating SOM stabilization, accumulation, and turnover are poorly understood.

Climate is a master controlling variable on C stocks and turnover in soil (Sayer et al. 2007). Climate change has been shown to have a complex impact on the $\mathrm{C}$ balance of forest ecosystems (Chapin et al. 2009; Fekete et al. 2011, 2017). These effects may include responses to elevated atmospheric $\mathrm{CO}_{2}$ as well as to changes in climate. Carbon stocks and accumulation in forests are also strongly impacted by land cover change and management. In Europe, the age and area of forests increased after release from high rates of wood cutting after the Second World War. Thus, release from intense harvest and potential effects of elevated $\mathrm{CO}_{2}$ on growth rates have increased European biomass and forest $\mathrm{C}$ sequestration capacity, partially offset in some of the $\mathrm{CO}_{2}$ emissions originating from the burning of fossil fuels (Luyssaert et al. 2010; Clark et al. 2016). However, forest ecosystems in many parts of the world are expected to become drier with climate change due to increases in evapotranspiration with warming and with more frequent and longer drought periods with the occurrence of weather extremes during the growing season (Galos et al. 2009). Dry summers, which are a feature of the Mediterranean climate, are predicted to become even more important to ecological processes in much of Central Europe and in certain parts of Western Europe (Domonkos 2003; Bartholy et al. 2007; Samaniego et al. 2018). 
Decreasing water availability and increasing heat stress, has caused a substantial change in wood stocks in many regions (Berki and Tar 1991; Tomiczek 1993; Fensham and Holman 1999; Nepstad et al. 2007; Van Mantgem et al. 2009; Allen et al. 2010; Tóth et al. 2011; Anderegget al. 2012), and may significant affect the $\mathrm{C}$ balance of forest soils (Fekete et al. 2017). Mean annual temperature (MAT), mean annual precipitation (MAP), as well as growing season temperature and precipitation, strongly affect SOM decomposition (Chen et al. 2000; Kotroczó et al. 2020). Precipitation, or water entering the soil through irrigation, has complex effects on both the quantitative and qualitative characteristics of SOC (Berthrong et al. 2012). Soil moisture will primarily affect SOC accumulation by influencing the quantity of plant $\mathrm{C}$ input to soils, as well as the decomposition rate of those $\mathrm{C}$ inputs as well as existing "stabilized" SOC (Zhou et al. 2008; O'Brien et al. 2010). Decreased water availability would be expected to result in lowered rates of SOM and litter turnover. However, increased temperature might be expected to increase rates of SOM turnover in temperate climates if water availability is sufficient (Bond-Lamberty and Thomson 2010; Bond-Lamberty et al. 2018; Chen et al. 2020), resulting in decreased soil $\mathrm{C}$ sequestration. In addition, climate change can increase growing season length and, in the absence of nutrient or water limitation (Sándor et al. 2020; Kocsis et al. 2018), can enhance biomass and litter production. An assumption built into many ecosystem models is that such increases in detrital inputs will also increase soil $\mathrm{C}$ sequestration, although the extent of the link and, in some cases, the direction of the relationship between litter inputs and soil $\mathrm{C}$ sequestration has recently come into question (Bowden et al. 2014; Fekete et al. 2016). Increasing root biomass could enhance soil C stocks, as most soil $\mathrm{C}$ is derived from roots (Rasse et al. 2005). Alternatively, increasing litter production and root/rhizosphere activity can lead to a positive, involving increased microbial activity that causes increased decomposition and soil respiration and a decrease in soil $\mathrm{C}$ sequestration (Fontaine et al. 2007; Kuzyakov 2010). Although low water availability would be expected to negatively affect tree biomass and leaf litter production, dry conditions could have a positive effect on soil $\mathrm{C}$ storage by damping decomposition processes through reduced soil microbial activity (Fekete et al. 2014, 2017). Clearly competing processes will act to determine changes in soil $\mathrm{C}$ stocks with changes in temperature and precipitation. Many studies, especially in water-limited ecosystems (e.g. in semi-arid grasslands), have observed decreased soil $\mathrm{C}$ with decreased water availability, or MAP (e.g. Tian et al. 2016, Jenny 1980; Burke et al. 1989; Zhou et al. 2002). In contrast, Meier and Leuschner (2010) reported that SOC concentration was $\sim 25 \%$ lower in beech forests with annual precipitation $>900 \mathrm{~mm} \mathrm{year}^{-1}$ compared to those with precipitation $<600 \mathrm{~mm} \mathrm{year}^{-1}$. Similarly, Chen et al. (2016) observed that SOC decreased with artificial increases in MAP in subtropical forests, likely due to more significant effects on SOC mineralization than on plant litter production.

To better understand the long-term impacts of climate on soil $\mathrm{C}$ cycling, we studied biological activity and $\mathrm{C}$ stocks along a climatic gradient in Hungary on similar parent materials. We argue that using a space-for-time gradient that is an area where climate patterns expected in the future already occur is an effective way to predict potential changes to soil $\mathrm{C}$ processes and pools. We hypothesized that temperature and precipitation, as combined into the Ellenberg's Quotient (EQ), would be a dominant control on SOC concentration across our gradient. We specifically hypothesized that microbial activity would be more sensitive to lowered water availability than plant litter production, and thus the effect of declining microbial activity with decreased water availability would be more significant than declining above- and below-ground litter production, so that SOM would accumulate in the soils of dry forests. We also recognized that soil parameters such as $\mathrm{Fe}, \mathrm{Ca}$, and $\mathrm{pH}$ are also affected by soil moisture status and all of these in turn can affect the accumulation of $\mathrm{C}$ in soils. The Carpathian Basin provides an excellent region to study soil $\mathrm{C}$ dynamics along a relatively wide climatic gradient in forests. We also suggest that processes taking place in these Carpathian Basin forest ecosystems can be used as models of the expected longerterm impacts of climate change on soil $\mathrm{C}$ cycling in temperate forests around the world. 


\section{Materials and methods}

Sites description and experimental design

The sites selected for our study occur along a climosequence in the Carpathian Basin where the original parent material and forest stand features are similar, but differ in climate, particularly in mean annual precipitation. The climate of Hungary is influenced by several factors, such as distance from the Atlantic Ocean and mountain and basin position, both of which result in a general precipitation decrease from west to east, and at the foot of the mountains, SEfacing sites are drier than NW-facing sites. We identified 30 forest sites located across Hungary. The climatic data of these sites were compiled from the CARPATCLIM (high-resolution database of the Carpathian Region-www.carpatclim-eu.org). The study area is classified as in the temperate climatic zone and is at the intersection of three macroclimatic regions: Continental, Oceanic, and to a lesser extent Mediterranean (Salamon-Albert et al. 2016). The differences in the selected sites were mainly due to which of the 3 macroclimatic effects dominated each site.

In order to find potential breakpoints to define climatic influences on the forest sites, we used a broken-stick regression model (Muggeo 2017). To include more ecologically relevant climate information - for example the fact that the largest temperature differences between sites occur in the summer (drought) period, we used a factor based on the EQ, (Ellenberg 1988; Salamon-Albert et al. 2016) as the basis for the broken-stick regression model. This factor was calculated for each site as the average July temperature $\left({ }^{\circ} \mathrm{C}\right)$ divided by mean annual precipitation (mm), multiplied by 1000 . The independent variable (e.g. C stock in soil) is then partitioned into three distinct intervals using the $\mathrm{R}$ program with the "segmented" package. Based on the model, we grouped our forests into three categories: humid forests, meso forests and dry forests (Table 1; Fig. 1). We also used vegetation associations to define different forest types, and found that the boundaries were extremely similar. Sessile oak (Quercus petraea) is a basic species in these three forest types. Hornbeam (Carpinus betulus) appears in meso forests, and European beech (Fagus sylvatica) appears in humid forests. Of the 30 forests, the classifications using the EQ criterion and using vegetation agreed except for two sites that were classified as dry forests using the EQ criterion that were be classified as meso forests using vegetation. This similarity can be explained by the fact that the changes in climate are followed relatively rapidly by a change in tree vegetation. It is important to note that the concepts of "humid" and "dry" we employ here are relative. In other more humid deciduous forest regions of North America or Western Europe, even our most humid forests would be classified as relatively dry.

Natural gradient studies have a strong potential to introduce confounding factors that make interpretation of differences among sites difficult. We minimized the potential for such confounding factors in two ways. First, we worked with a large number of sites so we could filter out random variations across the gradient. Second, we chose sites having similar characteristics with zonal oak seedling stands (mainly the Quercetum petraeae-cerris and Querco-Carpinetum community), and with deep soils formed from similar parent materials (loess and weathered dust both settled at the end of the Ice Age), and weathered to varying degrees over time). Only forests older than 60 years were selected, and the average age of the forest areas was 88 years. Stagnant wetlands and steep to medium slopes were excluded from this analysis to avoid erosion/deposition effects; only well-drained sites with flat or slight slopes (1-2\%) were selected.

There were no significant differences in annual mean temperature among sites, reinforcing that the gradient is primarily a precipitation gradient (MAT humid forests: $11{ }^{\circ} \mathrm{C} \pm 0.13$; meso forests: $11.2{ }^{\circ} \mathrm{C} \pm 0.2$; dry forests: $\left.11.3^{\circ} \mathrm{C} \pm 0.14\right)$. However, during the growing period (late April to late September), there are small temperature differences between the areas, though small, are more pronounced (humid: $17.7{ }^{\circ} \mathrm{C} \pm 0.12$; mesico: $18.4{ }^{\circ} \mathrm{C} \pm 0.15$; dry: $18.5{ }^{\circ} \mathrm{C} \pm 0.10$ ). Long-term precipitation averages range from 545 to $722 \mathrm{~mm}$. Due to these differences in precipitation, despite the similar bedrock and vegetation, different soil types developed among sites. The differences between the soils of the sites (Luvisols, Cambisols, Phaeozems, Chernozems) are explained by macroclimatic factors and associated vegetation in the past (Table 1). 
Table 1 Sites used in this analysis

\begin{tabular}{|c|c|c|c|c|c|}
\hline Name of sites & Site type & $\operatorname{MAT}\left({ }^{\circ} \mathrm{C}\right)$ & Mean temperature during the growing season $(\mathrm{C})$ & MAP (mm) & Type of soil \\
\hline 1. Bajánsenye & $\mathrm{H}$ & 11.1 & 17.9 & 722 & Gleyic Luvisols \\
\hline 2. Ispánk & $\mathrm{H}$ & 11.3 & 18.1 & 703 & Gleyic Luvisols \\
\hline 3. Szilvágy & $\mathrm{H}$ & 11.2 & 17.9 & 719 & argillic Luvisols \\
\hline 4. Ortaháza & $\mathrm{H}$ & 11.2 & 17.9 & 725 & argillic Luvisols \\
\hline 5. Bak-1 & $\mathrm{H}$ & 10.8 & 17.4 & 715 & argillic Luvisols \\
\hline 6. Bak-2 & $\mathrm{H}$ & 10.8 & 17.5 & 713 & argillic Luvisols \\
\hline 7. Bazita & $\mathrm{H}$ & 10.9 & 17.5 & 705 & argillic Luvisols \\
\hline 8. Felsőmarác & $\mathrm{H}$ & 11.3 & 18.1 & 691 & Gleyic Luvisols \\
\hline 9. Zalalövő & $\mathrm{H}$ & 10.8 & 17.4 & 721 & Gleyic Luvisols \\
\hline 10.Hagyárosbörönd & $\mathrm{H}$ & 11.1 & 17.8 & 688 & Luvisols \\
\hline 11.Aggtelek & $\mathrm{H}$ & 10.9 & 17.5 & 651 & Luvisols \\
\hline 12.Balatonendréd & $\mathrm{M}$ & 11.4 & 18.4 & 640 & Cambisols \\
\hline 13. Bag & D-M & 10.6 & 17.6 & 578 & Cambisols \\
\hline 14. Buják & M & 12.4 & 19.7 & 595 & Luvisols \\
\hline 15.Sirok & M & 11.4 & 18.4 & 583 & Luvisols \\
\hline 16. Hévízgyörk & D-M & 12.3 & 19.2 & 575 & Cambisols \\
\hline 17. Lulla-1 & $\mathrm{M}$ & 11.9 & 18.5 & 639 & Cambisols \\
\hline 18. Fulókércs & M & 11.4 & 18.7 & 601 & Luvisols \\
\hline 19. Szemere & $\mathrm{M}$ & 9.6 & 17.9 & 606 & Luvisols \\
\hline 20. Gagyvendégi & M & 10.8 & 18 & 601 & Luvisols \\
\hline 21. Fancsal & M & 11.4 & 18.7 & 592 & Cambisols \\
\hline 22. Síkfókút & $\mathrm{M}$ & 10.4 & 17.7 & 586 & Luvisols \\
\hline 23. Vécs & $\mathrm{D}$ & 10.8 & 17.6 & 565 & Phaeozems \\
\hline 24. Füle-1 & $\mathrm{D}$ & 11.7 & 18.7 & 577 & Chernozems \\
\hline 25. Demjén-Észak & $\mathrm{D}$ & 12.1 & 19.1 & 553 & Phaeozems \\
\hline 26. Demjén-Dél & $\mathrm{D}$ & 11.3 & 18.6 & 557 & Phaeozems \\
\hline 27. Kerecsend & $\mathrm{D}$ & 11.2 & 18.5 & 554 & Chernozems \\
\hline 28. Aszaló & $\mathrm{D}$ & 11 & 18.3 & 556 & Phaeozems \\
\hline 29. Füle-3 & $\mathrm{D}$ & 11.1 & 18.4 & 577 & Chernozems \\
\hline 30. Füzesabony & $\mathrm{D}$ & 11.3 & 18.6 & 545 & Chernozems \\
\hline
\end{tabular}

$H$ humid, $M$ meso, $D$ dry

Soil sampling and measurements

We established one randomly located $10 \times 10 \mathrm{~m}$ plot in every site under complete canopy cover. The soil was sampled three times from December 2017 through December 2018. Soil cores were collected from the $0-5,5-15$ and $15-30 \mathrm{~cm}$ layers in mineral soil with a $20 \mathrm{~mm}$ diameter Pürckhauer1175/1000 mm soil corer (Bürkle $\mathrm{GmbH}$ ) at five randomly selected locations in each plot and were combined to form composite samples for each layer. Soil samples were sieved to $<2 \mathrm{~mm}$ and hand-picked to remove roots and stones. Total $\mathrm{C}$ concentrations in ground and homogenized soil samples from all three depths were determined using a combustion analyzer (VarioMax $\mathrm{CN}$ analyser, ElementarAnalysensysteme $\mathrm{GmbH}$, Hanau, Germany). To analyze carbonate $\mathrm{C}$, replicate samples were heated in a muffle furnace at $450{ }^{\circ} \mathrm{C}$ for $16 \mathrm{~h}$, then measured using the combustion analyzer. Organic $\mathrm{C}$ was calculated as the difference between total $\mathrm{C}$ and carbonate $\mathrm{C}$ (Chichester and Chaison 1992).Values from samples collected in the fall of 


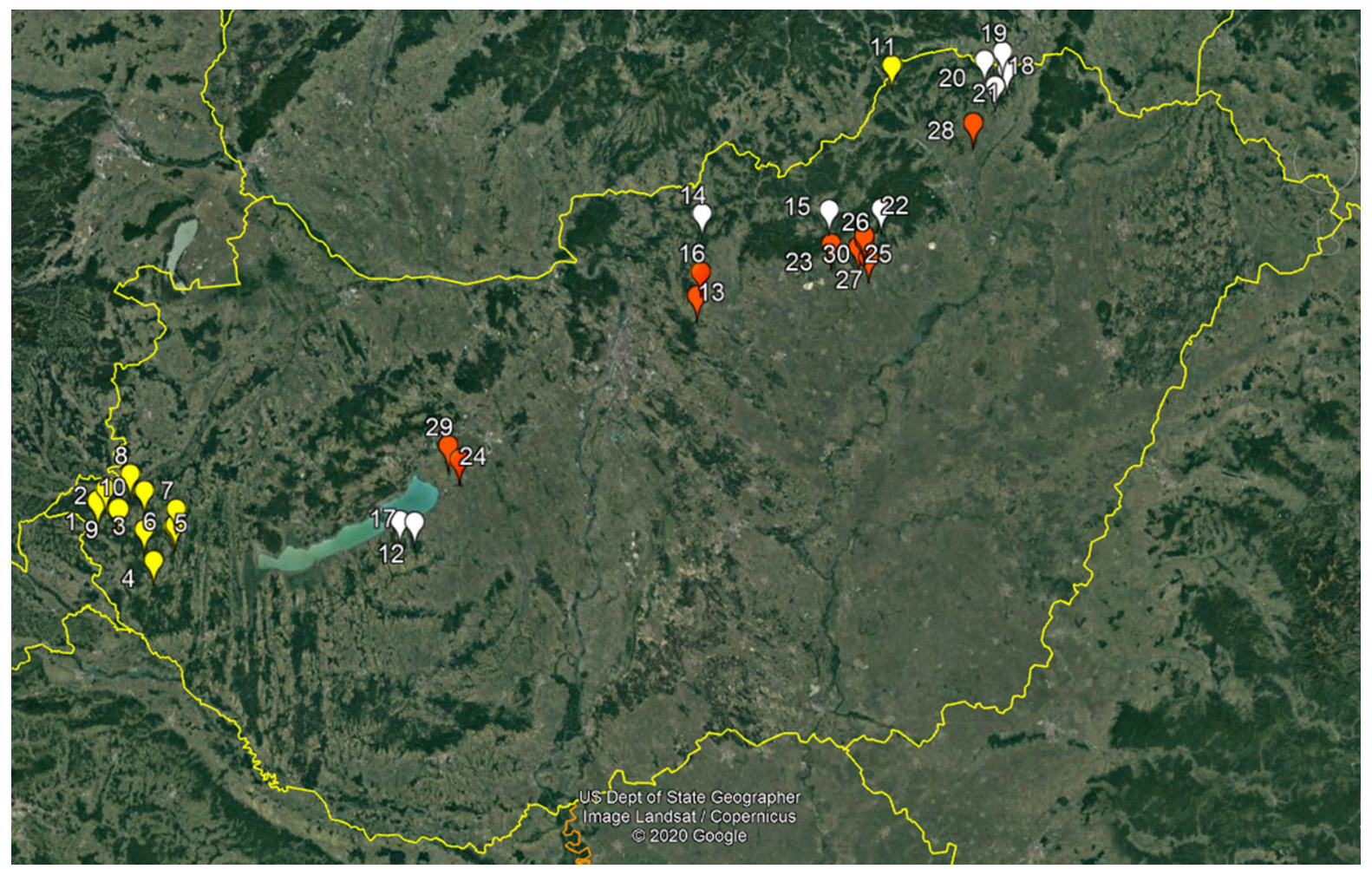

Fig. 1 Forest sites used in this study. Yellow tags represent humid forests, white tags represent meso forests, and orange tags represent dry forests. The sites are numbered according to Table 1

2017 and spring of 2018 were averaged so that for statistical analyses we had one value per site, thus ensuring the independence of the samples. Detritus production was measured using four quarter-square $\mathrm{m}$ plots in each forest site in early December 2018 and March 2019. Freshly fallen leaf litter was collected after peak leaf fall from square meter plots at each site then weighed on site, and a smaller amount of sample was taken to the laboratory where dried at $65^{\circ} \mathrm{C}$ then the dry mass was calculated based on these values.

Particle size distribution was determined after chemical treatment using laser diffraction. After treating the samples with $\mathrm{HCl}$ and $\mathrm{H}_{2} \mathrm{O}_{2}$ to remove carbonate and organic material (Buurman et al. 1996), $0.5 \mathrm{M} \mathrm{Na}_{4} \mathrm{P}_{2} \mathrm{O}_{7}$ was added the samples in order to disperse the particles. A Fritch Analysette 22 Microtech device was used in the range of $0.2-2000 \mu \mathrm{m}$. Grain sizes were calculated applying the Mie theory with 1.45 refractive index (Centeri et al. 2015). In order to compare particle size data of this study with those measured by the pipette method, the higher boundary of the clay fraction was chosen $(5.8 \mu \mathrm{m}$; Makó et al. 2017).

Soil samples for determining microbial activity were stored at $4{ }^{\circ} \mathrm{C}$ and the measurements were performed within 2 weeks after sampling. Soil fungal biomass was assessed using ergosterol content measured by HPLC in December 2018 (Béni et al. 2017). Dehydrogenase enzyme activity was measured in April 2018 according to Thalmann (1968) and Veres et al. (2013).

$\mathrm{Ca}$ and $\mathrm{Fe}$ concentrations were measured with a Thermo Fisher iCE 3300 flame atomic absorption spectrometer. Soils from the December 2017 sampling were prepared for elemental analysis using a CEM Mars 6 microwave digestion system, with a $0.5 \mathrm{~g}$ soil sample digested with $8 \mathrm{~mL} 67 \mathrm{w} / \mathrm{w} \%$ nitric acid. We only analyzed soil samples collected in December 2017 from 12 of the 30 sites, including only humid and dry forests, and in the upper $(0-5 \mathrm{~cm})$ layer.

Thermogravimetric (TG) and differential thermal (DTA) analyses were carried out simultaneously using a TG-DTA92 instrument (SETARAM, France)with a 
heating rate of $10{ }^{\circ} \mathrm{C}$ per Minute from 30 to $750{ }^{\circ} \mathrm{C}$ under air $\left(8 \mathrm{~L} \mathrm{~h}^{-1}\right)$, using procedures described by Montecchio et al. (2006) with $\sim 10 \mathrm{mg}$ samples. TG-DTA analysis involves continuous and simultaneous measurement of weight loss (TG) and energy change (DTA-DSC) during the heating of samples. An initial exothermic reaction $\left(\approx 300{ }^{\circ} \mathrm{C}\right)$ is generally produced by the decomposition of proteins and carboxyl groups, while the exothermic reaction at higher temperature $\left(\approx 450{ }^{\circ} \mathrm{C}\right)$ is related to the decomposition of more chemically refractory carbon such as aromatic compounds and saturated aliphatic chains. The mass loss can be used to compare the relative abundance of more or less labile $\mathrm{C}$ while the position of DTA peaks can be related to the structure and chemical composition of the sample. Soils for this analysis were collected in December 2017 and were subsamples of the soils used for elemental analysis.

Radiocarbon concentrations $\left({ }^{14} \mathrm{C}\right)$ were measured as described by Tefs and Gleixner (2012). Briefly, after decalcification with $\mathrm{HCl}$ and graphite production (Steinhof et al. 2017), the ${ }^{14} \mathrm{C}$ content of the samples was measured with accelerator mass spectroscopy (Micadas, IonPlus, Switzerland). Due to the high cost of radiocarbon measurements, we only analyzed soil samples from three humid and three dry forest sites, and in two layers $(0-5 \mathrm{~cm}, 5-15 \mathrm{~cm})$. Soil samples were also collected in December 2017. The collected soils were also incubated (at lab temperature, after airdrying and then rewetting, adjusting the moisture to $60 \%$ of water holding capacity), and the $\mathrm{CO}_{2}$ evolved during the incubation was collected for ${ }^{14} \mathrm{C}$ measurement (following methods described in Gaudinski et al. 2000). This provides a measure of the ${ }^{14} \mathrm{C}$ content of carbon being actively utilized by microbes. Radiocarbon data are expressed as $\Delta^{14} \mathrm{C}$, the difference in parts per thousand of the ratio of ${ }^{14} \mathrm{C} /{ }^{12} \mathrm{C}$ ratio in the sample, corrected to a $\delta^{13} \mathrm{C}$ signature of -25 , and that of a common standard (oxalic acid I) that has been decay corrected to 1950 (see Trumbore et al. 2016). Reported means and standard deviations are of the three analyses and are larger than the analytical uncertainties (usually $\sim 3$ per mille in $\Delta^{14} \mathrm{C}$ ).

Radiocarbon in soils collected over the last several decades often have $\Delta^{14} \mathrm{C}$ values greater than 0 per mille indicating the presence of "bomb" radio carbon added to the atmosphere by thermonuclear weapons testing since the early 1960s. As soils are open systems, to which $\mathrm{C}$ newly fixed from the atmosphere is continuously added and from which $\mathrm{C}$ is continuously lost by decomposition, the $\Delta^{14} \mathrm{C}$ values of soil organic $\mathrm{C}$ change with time and reflect how long the added $\mathrm{C}$ resides in soil and the degree to which it is diluted by $\mathrm{C}$ fixed prior to the period of 'bomb' influence (Trumbore 2009; Trumboreet al. 2016).

Modeling of radiocarbon data

Quantitative interpretation of radiocarbon data requires a model, and the structure of that model will determine the values of inferred parameters such as decomposition rates of organic matter. As the radiocarbon signatures of $\mathrm{CO}_{2}$ respired in incubations differs from those of the bulk organic matter for the same depth intervals in our study (see "Results" section), at least two soil organic carbon pools are required: one with faster cycling times that contributes more to respired $\mathrm{CO}_{2}$ fluxes, and one with slower cycling times that makes up more of the organic matter stock. We chose a simple, two-pool series model with first order decomposition rates for soil organic matter, and transfer of a fraction of the carbon from the fast to slow-cycling pool (see insert in Fig. 4, the two-pool series model of the SoilR package; Sierra et al. 2014). The model was assumed to be at steady state, with constant inputs arbitrarily set to $100 \mathrm{gC} \mathrm{m}^{-2}$ year $^{-1}$. There are three adjustable parameters: $\mathrm{k} 1\left(\mathrm{year}^{-1}\right)$, the decomposition rate of pool 1 (the fast-cycling pool), $\mathrm{k} 2$ year $^{-1}$ ), the decomposition rate of the slowcycling pool, and $\times 21$ (unitless), the fraction of total $\mathrm{C}$ lost from pool 1 (i.e. $\mathrm{k} 1 * \mathrm{Pool} 1$ ) that is transferred to Pool 2. We assume the model is at steady state, i.e. that carbon pool sizes and fluxes are constant over time. Thus, the amounts of carbon in pool 1 and pool 2 can be calculated as:

Pool $1\left(\mathrm{gC} \mathrm{m}^{-2}\right)=$ Inputs $/ \mathrm{k} 1$

Pool $2\left(\mathrm{gC} \mathrm{m}^{-2}\right)=\mathrm{x} 21 *$ Inputs $/(\mathrm{k} 1 * \mathrm{k} 2)$

The amounts of carbon calculated by the model can also be compared with inputs and stocks for the humid and dry soils as an additional test; however actual inputs (including root litter production rates and leaching from surface litter into mineral soil) are not quantified so these are relative measures. Initial radiocarbon signatures for the year of the model start (1900) were calculated as in Trumbore et al. (2016) for 
a steady state pool: Fraction Modern $=\mathrm{k} /(\mathrm{k}+$ lambda); where $\mathrm{k}$ is $\mathrm{k} 1$ or $\mathrm{k} 2$, and lambda is the decay constant for radiocarbon (1/8267 years). Fraction Modern are converted to $\Delta^{14} \mathrm{C}$ using Trumbore et al. (2016). The model was run from 1900 to 2020 with a time step of 0.5 years. For every year, we assumed fresh plant inputs would have the radiocarbon signature of the atmosphere (northern hemisphere zone 1, as described in Sierra et al. 2018).

The parameters $\mathrm{k} 1, \mathrm{k} 2$, and $\times 21$ were estimated using a Markov Chain Monte Carlo method (FME package; Soetaert and Petzoldt (2010). The R code used to run the model is given as the supplementary material and will be posted on the ISRaD web site on publication (www.soilradiocarbon.org). The cost function that was minimized compares the model predicted radiocarbon signatures of bulk organic matter (bulk $\left.k_{\text {mod }}\right)$ and respired $\mathrm{CO}_{2}\left(\mathrm{resp}_{\bmod }\right)$ in the year 2018.0 (i.e. January 2018) with the mean and standard deviation of three replicate measurements of bulk soil organic matter (bulk obs $_{\text {) }}$ and incubations (resp $\mathrm{pbs}_{\text {ob }}$ ) values from soil collected in December 2017:

cost $=\frac{\left(r e s p_{m o d}-r e s p_{o b s}\right)}{s t d e v\left(r e s p_{o b s}\right)^{2}}+\frac{\left(\text { bulk }_{m o d}-b_{u l k_{o b s}}\right)}{s t d e v\left(b u l k_{o b s}\right)^{2}}$

The model was run initially 300 to 1000 times to estimate best-fit initial parameters, after which the number of iterations for the Markov chain was 1000-3000 (with 1600-2850) accepted runs). As certain combinations of parameters lead to negative respiration values (giving a model error), these combinations were excluded by constraining the range of parameters used as lower and upper bounds for the MCMC runs (Soetaert et al. 2010).

\section{Statistical analyses}

SOC concentration, fungal biomass, enzyme activity, leaf litter production, and annual average precipitation among the forest types were compared by one-way ANOVA followed by Tukey's HSD post-hoc test. We applied regression analysis to correlate the EQ climate parameter to soil $\mathrm{C}$ content and soil fungal biomass to MAP. These statistical analyses were conducted using Statistica 8.0. In order to find potential breakpoints across the whole range of variables, we used the broken-stick regression model as described above (Muggeo 2017) using R.

\section{Results}

Regression analysis indicated strong negative correlation in the upper $30 \mathrm{~cm}$ of soils from our sites between mean annual precipitation (MAP) and SOC concentration $\quad(y=-0.0114 x+9.3005$, $\left.R^{2}=0.7781\right)$ as well as between the EQ value and SOC concentration $(y=0.1724 x-3.5158$, $R^{2}=0.7849$ ). The correlation and AIC (Akaike information criterion) $(34.6,33.7)$ values were more favorable with the EQ, thus we used this index for further analyses.

The broken stick model allowed us to separate boundaries of the three forest types, referred to here as humid, meso, and dry. EQ below 29.5 characterize humid forests, 29.5 to 36.56 define meso forests, and values above 36.56 define dry forests (Fig. 2).Within the each of three forest types, the slope and $R^{2}$ values of the relationship between EQ and SOC $(0-30 \mathrm{~cm})$ differed, although all relationships were positive (humid: $y=0.0616 x-0.3986, R^{2}=0.0579$; meso: $y=0.2049 x \quad-\quad 4.7381, \quad R^{2}=0.1902 ; \quad$ dry: $\left.y=0.3722 x-10.941, R^{2}=0.4565\right)$. Slope values indicate that the drier the forest, the stronger the relationship between climate parameters of the sites (EQ) and the $\mathrm{C}$ content of their soils, whereas within the humid forests, differences in EQ values had little effect on the $\mathrm{C}$ content of soils. Significantly higher soil $\mathrm{C}$ content was observed in the soils of the dry forests than in humid forest soils in all three soil horizons (Table 2), although leaf litter production was about $37 \%$ higher in humid forests (Table 3). The inorganic C (IC) concentration was very low, and was below detection limits in several cases. IC was higher in the soils of dry forests $(0.14 \pm 0.04 \mathrm{~g} \mathrm{IC} / 100 \mathrm{~g}$ dry soil compared to soils of the humid forests $(0.053 \pm 0.003 \mathrm{~g} \mathrm{IC} / 100 \mathrm{~g}$ dry soil $)$.

Soil analyses demonstrated that there were few significant differences in elemental properties among these types. The particle size distribution was similar across the soils; only average clay contents are shown for the upper $5 \mathrm{~cm}$, but proportions of sand and silt also showed little variation. The clay contents of the 3 site types do not significantly differ (Table 2). No significant differences were found in the $\mathrm{Fe}$ content of the humid and dry forest soils (humid: $20,723 \pm 1536$, dry: $21,497 \pm 1850 \mathrm{mgkg}^{-1}$ in the upper $5 \mathrm{~cm}$ ). However, the $\mathrm{Ca}$ content of the dry soils $\left(8207 \pm 2118 \mathrm{mg}^{-1} \mathrm{~kg}\right)$ was significantly greater 


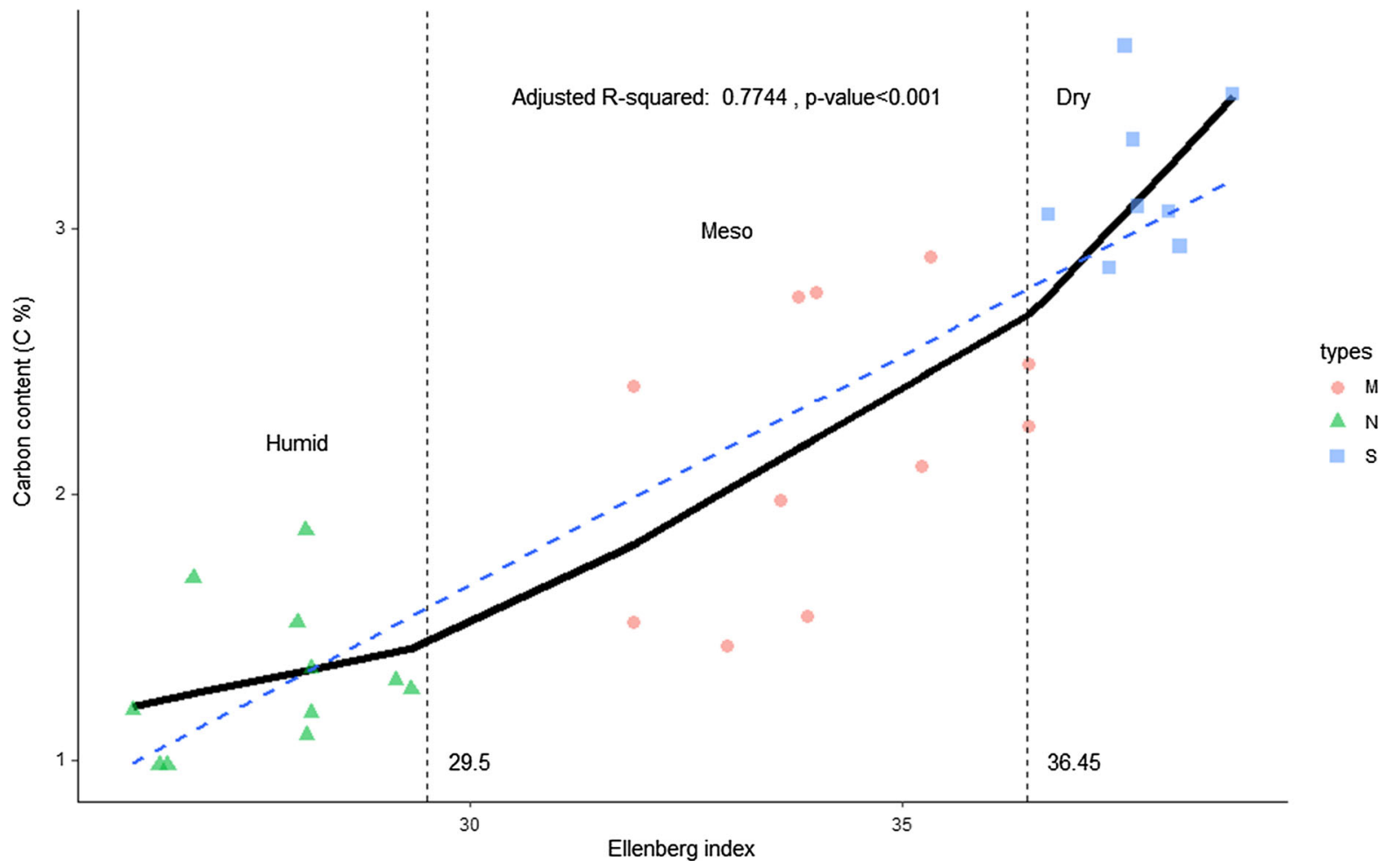

Fig. 2 Relationship between the Ellenberg index and soil C content based on 30 forested sites in Hungary. The 3 forest types were defined by the Broken Stick model using the Ellenberg

than that of the humid soils $\left(1154 \pm 327 \mathrm{mg}^{-1} \mathrm{~kg}\right)$, and $\mathrm{pH}$ of the two types were also significantly different (Table 2). There was also a strong negative correlation between Ca content and MAP $\left(\mathrm{R}^{2}=0.65\right.$ $\mathrm{p}=0.0027)$. We measured a much smaller difference in $\mathrm{Ca}$ content of leaf litter between dry $\left(16,274 \pm 899 \mathrm{mg}^{-1} \mathrm{~kg}\right)$ and humid forests $\left(11,233 \pm 1166 \mathrm{mg}^{-1} \mathrm{~kg}\right)$.

Dehydrogenase enzyme activity was significantly higher in humid forest soils than in meso or dry forest soils, and fungal biomass was also significantly greater in humid forests than in dry forests. (Table 4). Linear regression analysis indicates a strong correlation of soil fungal biomass with MAP (Adjusted $\mathrm{R}^{2}$ : 0.5405, $\mathrm{P}=0.00108$, Fig. 3).

The soils from the dry sites used for radiocarbon measurements averaged higher $\mathrm{C}$ content compared to soils from the humid sites (Table 5). Radiocarbon signatures of all samples averaged $>0$ per mil, indicating that most of the $\mathrm{C}$ is derived from bomb radiocarbon, i.e. $\mathrm{C}$ fixed in the last 60 years (Table 5). The rate of $\mathrm{CO}_{2}$ evolution in incubations, expressed index, where breaking points of the Ellenberg Index were 29.5 and 36.45 , and the results of regression analysis between Ellenberg index values and soil organic carbon stock

per gram soil $\mathrm{C}$, was lower in dry soils compared to humid soils (Table 5). Respired $\mathrm{CO}_{2}$ in incubations had $\Delta^{14} \mathrm{C}$ values higher than the atmosphere in 2017/8, and also higher than bulk soil radiocarbon values except in the $0-5 \mathrm{~cm}$ layer of the humid soil where values for bulk and respired radiocarbon overlapped. Bulk organic matter $\Delta^{14} \mathrm{C}$ values decreased with depth in all soils, but respired $\Delta^{14} \mathrm{C}-\mathrm{CO}_{2}$ increased or stayed constant with depth, increasing the difference in $\Delta^{14} \mathrm{C}$ between respired and bulk $\mathrm{C}$ in the deeper soil layer.

The two-pool model allows a more quantitative comparison of $\mathrm{C}$ cycling rates in humid and dry site soils by estimating the parameters that best reproduce observed radiocarbon values in respired $\mathrm{CO}_{2}$ and bulk soil simultaneously (Table 6). The best fit parameters are consistent with faster turnover times of $\mathrm{C}$ in humid soils compared to dry soils (Fig. 4.) The trajectory of $14 \mathrm{C}$ for these modeled parameters, including uncertainties, is shown in Fig. 5 for the $0-5 \mathrm{~cm}$ dry and humid site averages demonstrates the large uncertainties in using only respired and bulk $14 \mathrm{C}$ data at a single point in time to fit the models-however, it is also 


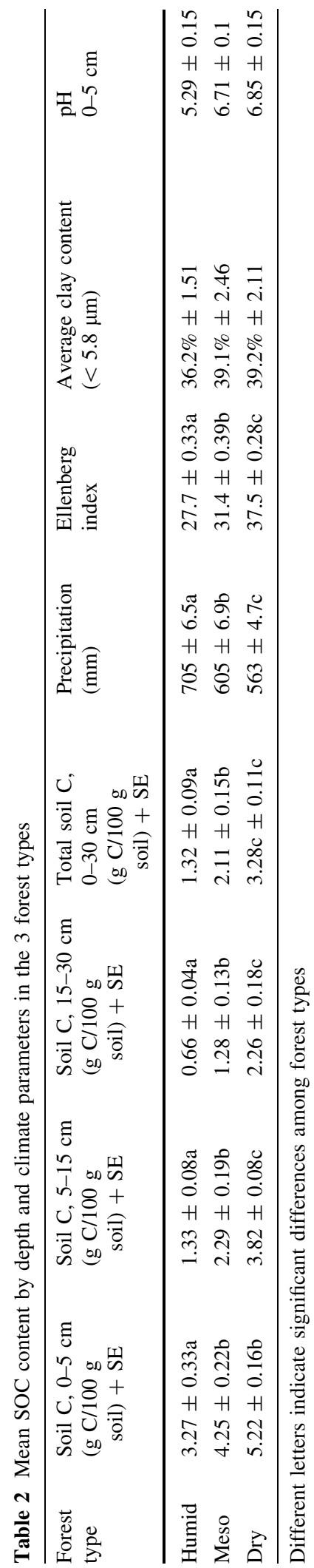

clear that they can detect differences in the fitted parameters. Turnover times (calculated as $1 / \mathrm{k} 1$ ) for the fast-cycling pool are faster in the humid pools, averaging 9.5 years (95\% CI 5.2- 15.1. years) for the humid soils but 17 years (6.6-40 years) for the dry soil in the $0-5 \mathrm{~cm}$ depth interval (Table 6). Differences in the slow pool are even more marked, 120 years (50-385) for the humid soils, but 230 years (110-490) in the dry soils. In humid soils, there is also more efficient transfer of $\mathrm{C}$ from fast to slow pools, though generally $>95 \%$ of total $\mathrm{C}$ inputs are respired from the fast-cycling pool. The models predict bulk $\mathrm{C}$ storage that average 55 times the annual $\mathrm{C}$ input flux for dry soils (95\% CI 15-64 times; 0-5 cm layer), but 38 times (95\% CI 9-96 times), consistent with higher $\mathrm{C}$ storage in dry soils having similar inputs. Although decay rates as well as differences between humid and dry soils decline with depth, the patters of faster turnover in humid site soils, as well as greater efficiency of transfer from fast to slow pools is maintained in the 5-15 cm intervals (Table 6). For all soil samples analyzed by thermogravimetry, three main peaks in the TG-DTA curves were observed: one endothermic peak and two exothermic peaks. The first peak appeared at a temperature of $<100{ }^{\circ} \mathrm{C}$, and was related to the loss of hygroscopic water. The second and third peaks occurred at temperatures of approximately $300{ }^{\circ} \mathrm{C}$ and $500{ }^{\circ} \mathrm{C}$ (Fig. 6).

The first exothermic reaction for dry soils occurred at $337 \pm 5^{\circ} \mathrm{C}$ with a mass loss of $6.8 \%$ was considered to be the result of thermal combustion of polysaccharides, decarboxylation of acidic groups and dehydration of hydroxylate aliphatic structures. A second exothermic peak at $506 \pm 5{ }^{\circ} \mathrm{C}$ with a mass loss of $3.4 \%$ was related to the combustion of aromatic structures and cleavage of $\mathrm{C}-\mathrm{C}$ bonds. Meso soils samples showed two exothermic reaction at $336 \pm 5{ }^{\circ} \mathrm{C}(6.0 \%)$ and $510 \pm 5{ }^{\circ} \mathrm{C}(3.0 \%)$ respectively. The first exothermic peak for humid soils occurred at a lower temperature $\left(320 \pm 5{ }^{\circ} \mathrm{C}\right)$ compared to that of dry or meso soils, with a mass loss of $4.9 \%$. The second exothermic peak occurred at a higher temperature compared to that of dry or meso soils: $530 \pm 5{ }^{\circ} \mathrm{C}$ with a mass loss of $2 \%$ (Fig. 6). 
Table 3 Litter mass on the forest floor in the three forests types across this study $( \pm$ SE) at the same locations, measured at 2 times

\begin{tabular}{lcc}
\hline Forest type & $\begin{array}{l}\text { Weight of the leaf litter in } \\
5 \text { December } 2018 \\
\left(\mathrm{~g} \mathrm{C} \mathrm{m}^{-2}\right)\end{array}$ & $\begin{array}{l}\text { Weight of the leaf litter in } \\
\text { same places in 26 March 2019 } \\
\left(\mathrm{g} \mathrm{C} \mathrm{m}^{-2}\right)\end{array}$ \\
\hline Humid & $992 \pm 101.4^{\mathrm{b}}$ & $798 \pm 60.7^{\mathrm{a}}$ \\
Mezo & $681 \pm 24.9^{\mathrm{a}}$ & $608 \pm 51.9^{\mathrm{a}}$ \\
Dry & $723 \pm 46.4^{\mathrm{a}}$ & $647 \pm 47.9^{\mathrm{a}}$
\end{tabular}

Different letters indicate significant differences among forest types

Table 4 Dehydrogenase activity and fungal biomass content of the different forest types in the upper $0-5 \mathrm{~cm}$ soil layer

\begin{tabular}{lll}
\hline Forest types & $\begin{array}{l}\text { Dehydrogenase activities } \\
\left(\mathrm{TPF} \mu \mathrm{g} \mathrm{g}^{-1} \text { dry soil }\right) \pm \mathrm{SE}\end{array}$ & $\begin{array}{l}\text { Biomass of fungi } \\
(\mathrm{mg} / \mathrm{g} \text { soil }) \pm \mathrm{SE}\end{array}$ \\
\hline Humid & $3.99 \pm 0.57^{\mathrm{b}}$ & $1.51 \pm 0.068^{\mathrm{b}}$ \\
Meso & $1.86 \pm 0.26^{\mathrm{a}}$ & $1.42 \pm 0.117^{\mathrm{b}}$ \\
Dry & $1.85 \pm 0.49^{\mathrm{a}}$ & $0.94 \pm 0.054^{\mathrm{a}}$ \\
\hline
\end{tabular}

Different letters indicate significant differences among forest types

\section{Discussion}

We initially hypothesized that temperature and precipitation, as combined into the EQ, would be a dominant control on SOC concentration across our gradient, and indeed, there was a strong correlation between SOC concentration and both annual precipitation values or the EQ. Significantly higher soil C concentrations were observed in the soils of the dry forests than in humid forest soils in all three soil horizons even though leaf litter production was higher in humid forests, and soils in the drier sites store 2.5 times more organic $\mathrm{C}$ than soils in humid forests. This added $\mathrm{C}$ could either be unprotected, not fully degraded particulate organic matter $(\mathrm{POM})$ or it might represent an increase in mineral-associated organic matter (MAOM). Given greater litter inputs in the humid sites, the inference is that the greater $\mathrm{C}$ storage in dry sites must be linked to slower overall turnover rates. Modeling using radiocarbon data indicates that
Fig. 3 Linear regression analyzes of soil fungal biomass with MAP in some Hungarian dry, meso and humid forest sites

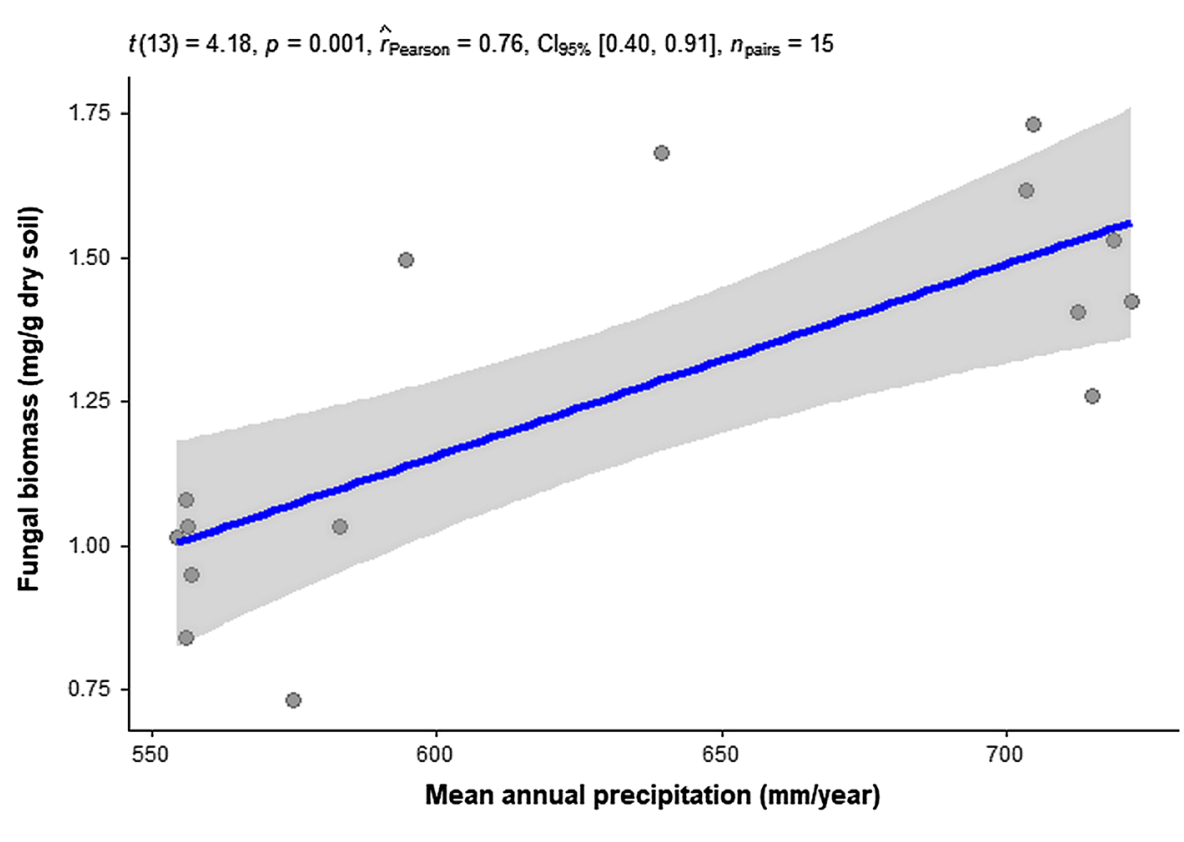

In favor of null: $\log _{c}\left(\mathrm{BF}_{01}\right)=-3.64, r_{\text {Csucty }}^{\mathrm{Jzs}}=0.71$ 
Table 5 Radiocarbon in bulk soil organic matter and heterotrophically respired $\mathrm{CO}_{2}$ for dry and humid forest end member soils

\begin{tabular}{|c|c|c|c|c|c|c|c|c|c|}
\hline Forest type & Depth $(\mathrm{cm})$ & $\% \mathrm{C}$ & SD & $\Delta^{14} \mathrm{C}$ Bulk SOM & SD & $\begin{array}{l}\text { Incubation flux (mgC } \\
\left.\text { g-soilC }{ }^{-1} \mathrm{~d}^{-1}\right)\end{array}$ & stdev & $\begin{array}{l}\Delta^{14} \mathrm{C} \\
\text { Respired } \mathrm{CO}_{2}\end{array}$ & SD \\
\hline \multirow[t]{2}{*}{ Humid } & $0-5$ & 3.2 & 1.2 & 58.9 & 15.1 & 2.57 & 0.25 & 54.0 & 13.1 \\
\hline & $5-15$ & 1.5 & 0.2 & 27.1 & 9.1 & 2.34 & 0.47 & 62.4 & 4.6 \\
\hline \multirow[t]{2}{*}{ Dry } & $0-5$ & 5.5 & 1.3 & 31.9 & 21.6 & 1.97 & 0.65 & 62.9 & 13.5 \\
\hline & $5-15$ & 4.6 & 1.9 & 17.8 & 16.2 & 1.87 & 0.38 & 62.4 & 4.6 \\
\hline
\end{tabular}

Values are the means and standard deviations for three replicate samples in each case. Radiocarbon data are expressed as $\Delta^{14} \mathrm{C}$, the difference in the ${ }^{14} \mathrm{C} /{ }^{12} \mathrm{C}$ ratio of the sample, corrected to a $\delta^{13} \mathrm{C}$ signature of -25 , divided by a common standard decay corrected to 1950 (see Trumbore et al. 2016)

Table 6 Results of the Markov-Chain Monte Carlo parameter estimation for the Dry and Humid soils, and the two different depth intervals

\begin{tabular}{|c|c|c|c|c|c|c|c|c|c|}
\hline Soil & Depth $(\mathrm{cm})$ & Para-meter & Best-fit & Mean & SD & Count & $\begin{array}{l}\text { Lower } \\
95 \% \mathrm{CI}\end{array}$ & $\begin{array}{l}\text { Upper } \\
95 \% \mathrm{CI}\end{array}$ & $\begin{array}{l}\text { Turnover time (best-fit, } \\
95 \% \text { CI range) (year) }\end{array}$ \\
\hline \multirow[t]{3}{*}{ Dry } & \multirow[t]{3}{*}{$0-5$} & $\mathrm{k} 1$ & 0.0573 & 0.0880 & 0.0323 & 2850 & 0.0247 & 0.1514 & $17.4(6.6-40)$ \\
\hline & & $\mathrm{k} 2$ & 0.0044 & 0.0056 & 0.0018 & 2850 & 0.0021 & 0.0092 & $230(110-490)$ \\
\hline & & $\times 21$ & 0.0202 & 0.0121 & 0.0064 & 2850 & -0.0004 & 0.0246 & \\
\hline \multirow[t]{3}{*}{ Dry } & \multirow[t]{3}{*}{$5-15$} & $\mathrm{k} 1$ & 0.0640 & 0.0640 & 0.0172 & 2850 & 0.0304 & 0.0976 & $15.6(10.2-33)$ \\
\hline & & $\mathrm{k} 2$ & 0.0025 & 0.0047 & 0.0017 & 2850 & 0.0014 & 0.0080 & $400(126-690)$ \\
\hline & & $\times 21$ & 0.0130 & 0.0180 & 0.0065 & 2850 & 0.0053 & 0.0306 & \\
\hline \multirow[t]{3}{*}{ Humid } & \multirow[t]{3}{*}{$0-5$} & $\mathrm{k} 1$ & 0.1056 & 0.1285 & 0.0319 & 2850 & 0.0661 & 0.1910 & $9.5(5.2-15.1)$ \\
\hline & & $\mathrm{k} 2$ & 0.0085 & 0.0113 & 0.0045 & 2850 & 0.0026 & 0.0201 & $120(50-385)$ \\
\hline & & $\times 21$ & 0.0379 & 0.0302 & 0.0147 & 2850 & 0.0014 & 0.0591 & \\
\hline \multirow[t]{3}{*}{ Humid } & \multirow[t]{3}{*}{$5-15$} & $\mathrm{k} 1$ & 0.0897 & 0.1041 & 0.0375 & 1600 & 0.0305 & 0.1777 & $11.1(5.6-33)$ \\
\hline & & $\mathrm{k} 2$ & 0.0047 & 0.0050 & 0.0008 & 1600 & 0.0034 & 0.0066 & $210(150-300)$ \\
\hline & & $\times 21$ & 0.0273 & 0.0245 & 0.0075 & 1600 & 0.0099 & 0.0392 & \\
\hline
\end{tabular}

Given for each model parameter (k1 and k2, units of 1/year, $\times 21$ is unitless) are the parameters providing the overall best-fit, as well as the overall mean and standard deviations for all accepted runs (Count). The upper and lower 95\% confidence intervals are also given. Turnover times are calculated from $1 / \mathrm{k} 1$ and $1 / \mathrm{k} 2$ and given in years

rates of $\mathrm{C}$ turnover are indeed slower both in faster cycling pools that dominate microbial respiration, and the slower cycling pools that make up the majority of soil organic matter mass. Patterns of SOC turnover do not always relate well to climate (Epstein et al. 2002) and the effects of climate change on soil C stocks are quite variable (Smith and Fang 2010; Gestel et al. 2018).

Although the parent materials of all sites were similar, climate has a significant effect on pedogenesis and nutrient leaching. The accumulation of organic matter in soils is regulated by a number of stabilizing factors such as clay, sesquioxides and $\mathrm{Ca}$ content of soils (Singh et al. 2018). Although no significant differences were found in the clay and $\mathrm{Fe}$ contents among soils of the different forest types, $\mathrm{pH}$ and $\mathrm{Ca}$ were both significantly higher in the dry soils, likely due to the higher degree of leaching in the humid areas. The leaching may have affected, directly or indirectly, the SOM content and turnover rate differences between humid and dry forest soils. $\mathrm{CaCO}_{3}$ can play a prominent role in aggregate stability and thus increase occluded SOC; it may also play a role in SOC sorption (Rowley et al. 2018). Similarly, pH effects have a critical role in SOC stabilization through effects on $\mathrm{Ca}$ as well as on $\mathrm{Al}^{3+}$ or $\mathrm{Fe}^{3+}$ and their poorly 


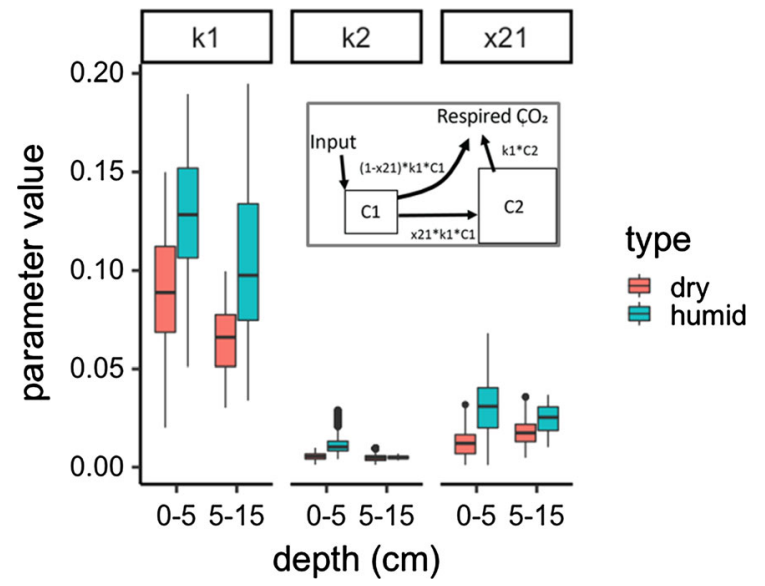

Fig. 4 Boxplot of the values derived from Markov Chain Monte Carlo fitting of parameters to observed bulk and respired radiocarbon values (see Table 6 for values). Inset: the model structure (two pool series model) indicating parameters relation to pools. Units are year ${ }^{-1}$ for k1 (overall first order decomposition rate for the fast-cycling pool 1) and k2 (first order decomposition rate for slow-cycling pool 2). The parameter $\times 21$ is the fraction of carbon leaving pool $1(\mathrm{k} 1 *$ amount of $\mathrm{C}$ in pool 1) that is transferred as inputs to pool 2

crystalline forms that are known to stabilize SOC. While these elemental differences can be observed in forest sites in equilibrium and develop over centuries, they likely will not appear over the timescale of expected anthropogenic climate change, and thus forests thrust into climate disequilibrium might show different patterns from what we have observed here. Although in the case of $\mathrm{Ca}$, we found that the leaf litter accumulate $\mathrm{Ca}$, so when comparing humid and dry forests, the difference is much smaller than in the case of $\mathrm{Ca}$ content of soils. This suggests in the climate range we studied that if leaching from soils decreases due to drier climate, previously Ca-poor soils may increase their $\mathrm{Ca}$ content mainly in the upper soil layer, if leaf litter has a significantly higher Ca content than the soil, which may also help stabilize SOM.

We used radiocarbon to identify soil $\mathrm{C}$ pool cycling on two timescales: (1) a fast pool that contributes the most to microbially respired $\mathrm{C}$ that likely represents the timescale for breakdown of (pre-aged) roots or other plant matter and (2) a slower pool, which likely integrates timescales of stabilization of organic $\mathrm{C}$ on clay mineral surfaces, sesquioxides or stabilized as $\mathrm{Ca}$ humates. Although uncertainties are large, the simultaneous requirement of the model to fit both the bulk and respired ${ }^{14} \mathrm{C}$ data demonstrates faster turnover of
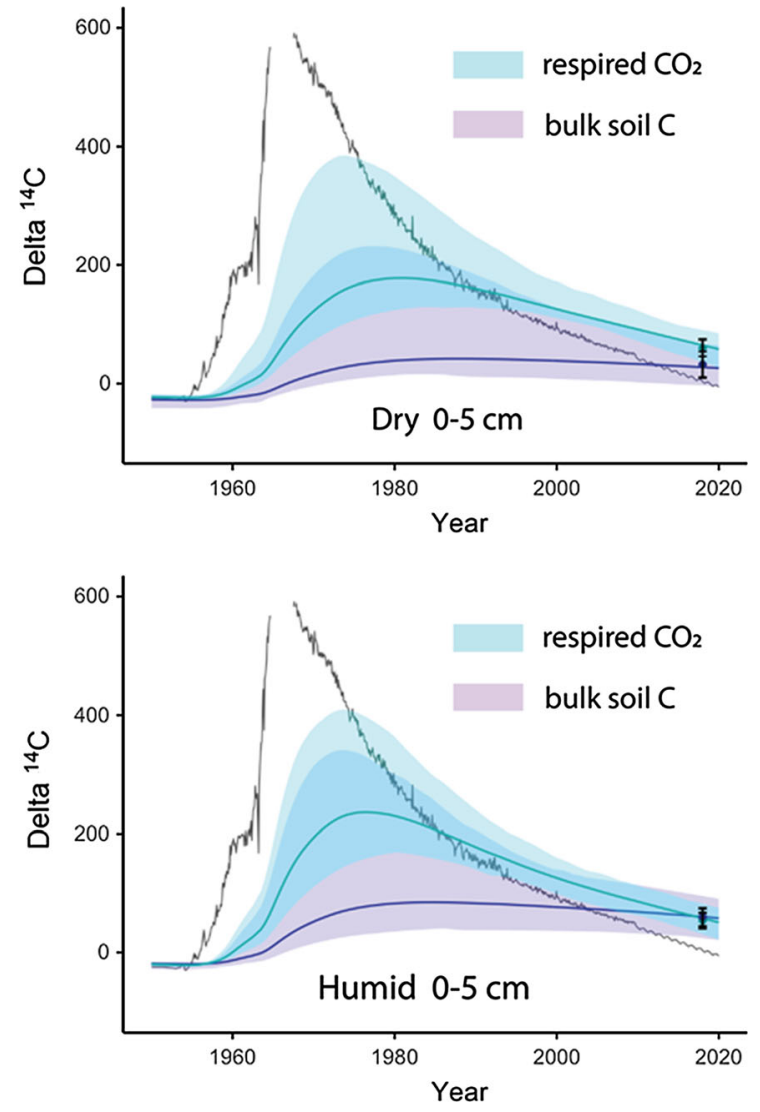

Fig. 5 Model best-fit parameters (lines) and 95\% confidence intervals (shaded regions) for respired (cyan/blue) and bulk soil (purple) radiocarbon for the $0-5 \mathrm{~cm}$ soil layers of dry (top) and humid (bottom) soils. Observations (with points showing means and error bars showing standard deviation) The darker line shows the atmospheric radiocarbon history from 1950 to 2020 used for the input to the model. Confidence intervals were produced using the SenseRange function of the FME R package (Soetaert and Petzoldt 2010). Briefly parameters were randomly sampled from a range that covered the $95 \%$ confidence intervals for each parameter (see Table 6), and the two-pool series model results were stored (100 times in total). These show the large uncertainties involved with having only two points at one time period to constrain model parameters, but demonstrate how additional time points would provide much stronger constraints

both fast and slow pools at the humid sites. The more efficient transfer of $\mathrm{C}$ from fast to slow pools in the humid sites inferred from the models might be related to either higher microbial $\mathrm{C}$ efficiency (less $\mathrm{C}$ respired to build biomass) or could reflect overall higher microbial biomass/activity in humid soils. These results support a role for differences in microbial activity and microbial community composition as being partly responsible for differences in $\mathrm{C}$ turnover 
Fig. 6 Thermogravimetric data obtained for humid, meso, and dry forest soils in upper 0-5 cm layer. The mass loss related to the two main exothermic reactions (Exo_I and Exo_II) were reported. Bars correspond to standard error $( \pm \mathrm{SE})$

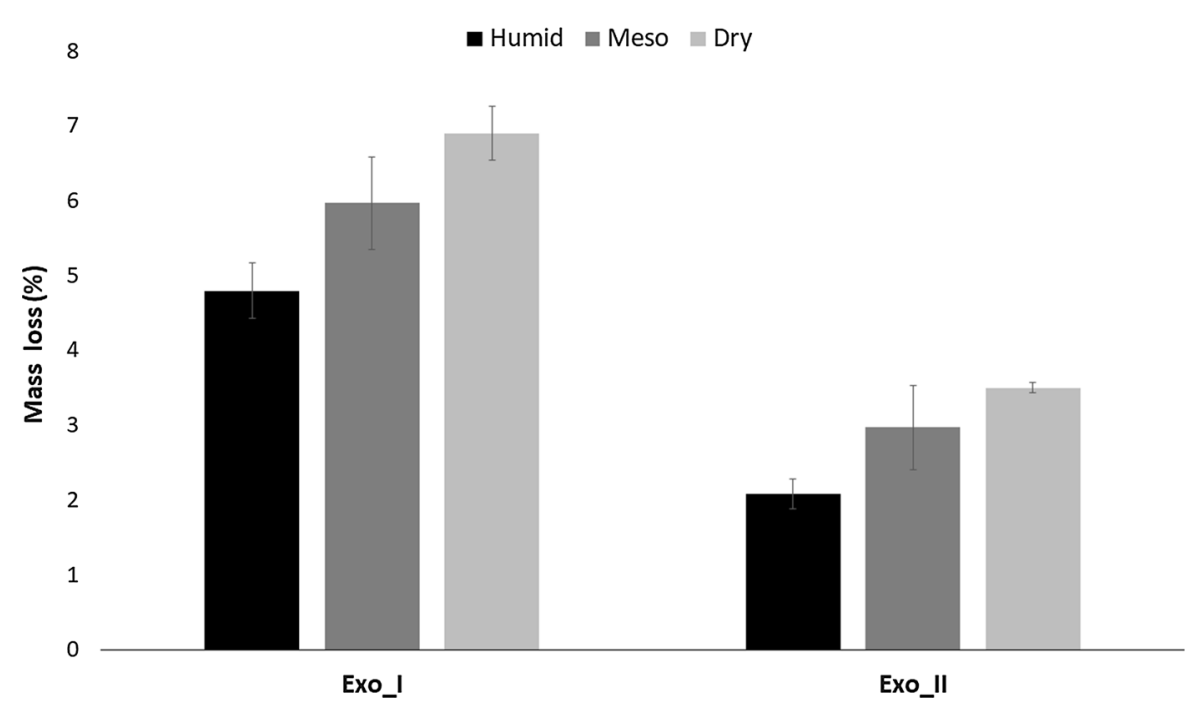

between soils of dry and humid forests. Furthermore, our previous litter manipulation studies have shown that a drier climate reduces the priming effect in the soil of dry forests (Fekete et al. 2014), and the radiocarbon data suggest that any priming effect is not large enough to make up for overall slower $\mathrm{C}$ turnover rates at drier sites.

Differences in the microbial activity between dry and humid areas were assessed by comparing enzyme activities and fungal biomass as a function of precipitation. Dehydrogenase activity is an indicator of the microbial redox system and the oxidative activity of the soil (Trevors 1984), and higher dehydrogenase activity was found in the upper $5 \mathrm{~cm}$ of the soil of humid forests than in dry forests. Since the dehydrogenase enzyme is active only within the living cell, the activity of the enzyme shows the activity of living microbial biomass (Szili-Kovács et al. 2011; Uzarowicz et al. 2020). The intensity of degradation can also be significantly influenced by the fungal biomass of soils, as saprophytic fungi play a particularly important role in forest soils, especially in acidic soils. Immediately after the main litterfall during autumn, the amount of litter on the forest floor per unit area was significantly higher in humid forests than in dry and meso forests. In spring, the difference between forest types decreased and was not significant presumably due to more intensive degradation in humid forests.

SOM quality also differed among our sites. Thermal stability of SOM is found to be strongly correlated with chemical composition and biological decomposition (Zhou et al. 2015; Peltre et al. 2013). Labile and recalcitrant SOM were considered to have decomposed within temperature ranges of 200-400 ${ }^{\circ} \mathrm{C}$ (Dell'Abate et al. 2002; Montecchio et al. 2006) and $400-600{ }^{\circ} \mathrm{C}$ (Francioso et al. 2005; Rovira et al. 2008) respectively. We tested whether there were differences in chemical quality using thermogravimetry analysis, which demonstrated significantly greater loss of SOM at higher temperatures (about $500-570{ }^{\circ} \mathrm{C}$ ) in dry forest $(34 \%$ loss) soils compared to humid $(29 \%)$ soils ( $\mathrm{p}<0.05)$, with losses in meso forests similar to those in humid forests. This suggests that dry forest soils have a higher proportion of compounds with higher thermal stability (e.g., aromatic molecules) than humid forest soils. The amount of the more difficult-to-degrade molecules was $67 \%$ higher in the $0-5 \mathrm{~cm}$ soils of dry forest than in the soils of humid forest whereas this difference was only $39 \%$ for the more easily degradable substances in upper soil layer. The rate of mass loss at higher temperatures in dry forest soils was significantly higher (13\%), which may indicate that more resistant substances accumulate (e.g. lignin), or else more stable mineral-associated organic compounds form than in humid forest soils. The higher degree of leaching and decomposition in our humid areas, which we argue led to a decrease in $\mathrm{Ca}$ and $\mathrm{C}$ concentration, likely resulted in a decreasing of $\mathrm{Ca}$-organic carbon complexes (e.g. Ca-humates) characterized by high thermal stability (Buurman et al 2002). 
What else could lead to changes to soil $\mathrm{C}$ levels in forests experiencing drought, and not just equilibrium dry conditions? Under drying conditions or increased drought, we suggest that drought initially increases tree mortality and thus increase detrital inputs to the forest floor, and yet decreases the rate of decomposition, thus increasing soil $\mathrm{C}$ stores in drought-affected forest areas (Fekete et al. 2017). Increased tree mortality results in more woody material added to the forest floor which decomposes much slower than non-woody foliage litter and might have different effects on soil $\mathrm{C}$ sequestration than might increased leaf litter inputs (e.g. Cotrufo et al 2013). The change in litter quality due to the drier climate can also affect the speed of litter decomposition (Santonja et al. 2015). This transient increase in soil $\mathrm{C}$ storage from tree mortality is expected to be mostly particulate, plant-derived $\mathrm{C}$, rather than mineral-associated organic matter (MAOM), which is determined both by mineralogy and climate as well as detrital inputs (Rasmussen et al. 2018). Certainly, maximum soil C storage capacity will change as new equilibrium levels develop, and in forests, these new equilibrium levels might take decades or centuries to form, given the longevity of trees and rates of response to a slowly changing climate. The significant differences between the three forest types were not due to increase tree mortality but to the long-term effects of a drier climate. Our studies have shown that the drier climate can develop and sustain the higher SOC concentration of forest soils over a longer period of time.

Dry forests are at the limit of their drought tolerance, which may be related to the fact that oak decline was significantly higher in dry sessile oak forests than in humid sessile oak forests in Carpathian Basin (Mátyás et al. 2018). Our previous studies have shown that increased oak decline and the drier climate in the forests has also increased the $\mathrm{C}$ content of forest soils over the last 4 decades (Berki and Tar 1991; Berki et al. 2014; Fekete et al. 2017).

However, this increase is too small (in the upper $25 \mathrm{~cm}$ soil layer the SOC content increased by about $28 \%$, and at one meter level the increase was only $15 \%$ Fekete et al. 2017) to explain the huge difference we observed between forests that have presumably experienced dry, meso, and humid forests conditions over a longer time.

Although the organic C stock of soils in the Carpathian Basin forests have developed over hundreds and even thousands of years, the $\mathrm{C}$ content of soils may decrease or increase significantly over a few decades or even years due to changing climatic or management conditions (Kotroczó et al. 2008; Fekete et al. 2011), and biological processes in soils can change even faster (Fekete et al. 2008; Béni et al. 2014; Błońska et al. 2019). Different soil C pools have different turnover rates and thus will respond to changing climate over different timescales. For example, dissolved organic matter decomposes relatively quickly, depending on compound type, and thus should respond to climate within a few years (Brady and Weil 1999), it easy to understand why soils could lose half or even two-thirds of their organic carbon stock over a few years or decades, not including losses due to erosion if the environmental conditions change significantly (Kramer and Chadwick 2018).

Under global warming, the temperature dependence of soil C pools will be critical factors determining SOC stock changes (von Lützow and KögelKnabner 2009; Wiesmeier et al. 2014). Our results show that the effect of changes in the EQ also can be extremely significant for SOC concentration. However, these effects are most pronounced in drier forest soils, while hardly detectable in humid forests. This is probably because the soil moisture value is within the optimal range for the decomposing organisms in these areas and the differences within the range do not have a significant effect on these organisms. Our radiocarbon data indicate that "bomb" $\mathrm{C}$ penetrates a majority of the organic matter in the top $15 \mathrm{~cm}$ of all soils in this region. Hence we expect soils to respond within centuries to changes in climate or vegetation.

\section{Conclusions}

The strong correlations of SOC concentration with climate (MAP and EQ), suggest that future changes in these variables can significantly affect the carbon content of the region's soils in the longer term, in line with trends that have emerged in the past. At our sites, $\mathrm{Ca}$ content decreased with increasing MAP and decreasing EQ, and SOC also declined; thus, the more rapid decomposition at higher soil moisture content (higher MAP) and lower Ca level are primarily responsible for the differences in carbon concentration values among our studied regions or individual sites. Our results highlight the role of drought stress in the 
dry hot summer areas on the intensity of degradation processes and, consequently, the accumulation of SOC. These effects may also influence regions that are still currently classified as meso and humid forests. The predicted near-term direction in climate in the Carpathian Basin is for overall reduction in precipitation, and thus we predict a reduction in above ground biomass but at least a short-term increase in SOC across all of our sites. An important question is what happens to the SOC content of soils in the longer term, where forests also disappear due to drought. Predicting future changes in $\mathrm{C}$ storage in this region depends on improving our understanding of factors controlling the current turnover rates of SOC, and why these vary among otherwise similar sites. Changes to the quality and quantity of litter inputs (especially belowground) may be as significant to changes in soil $\mathrm{C}$ stocks as are direct effects of climate on soil processes. Understanding the mechanisms (from litter chemical composition to soil mineralogy to microbial community composition) that stabilize soil $\mathrm{C}$ over centuries will be critical for a full assessment of how ecosystems will both respond to climate change and themselves feed back to the climate system.

Acknowledgements Open access funding provided by Szent István University. IF Project no. 125688 and 127722 have been implemented with the support provided by the National Research, Development and Innovation Fund of Hungary, financed under the $\mathrm{KH}_{-} 17$ funding scheme and ERC_16_M funding scheme. BM was supported by Bolyai Research Scholarship of the MTA; ÚNKP-19-4 New National Excellence Program of the Ministry of Human Capacities. ST acknowledges support from the European Research Council (Horizon 2020 Research and Innovation Programme, grant agreement 695101; 14Constraint) and thanks Shane Stoner and Carlos Sierra for their help with modeling radiocarbon in R. ZsK Project no. 126478 has been implemented with the support provided by the National Research, Development and Innovation Fund of Hungary, financed under the KH_17 funding scheme.

Author contributions All authors contributed equally to the development of the ideas and authoring of the paper. IF implemented the surveys and managed the data collection and evaluation of results. IB conducted field work and provided forest ecological data. KL made English language corrections. ST provided radiocarbon analyzes. OF and PG provided interpretation of the thermogravimetric measurements. DM performed thermogravimetric measurements. GV performed the statistical analyses. AB conducted chemical and fungal biomass analyses. MM and ID performed soil C measurements. BM performed soil grain size composition tests. KJ assisted with field work and identification of soil types. ZK performed field work, laboratory and biological analyses.

\section{Compliance with ethical standards}

Conflicts of interest The authors declare no competing interests.

Open Access This article is licensed under a Creative Commons Attribution 4.0 International License, which permits use, sharing, adaptation, distribution and reproduction in any medium or format, as long as you give appropriate credit to the original author(s) and the source, provide a link to the Creative Commons licence, and indicate if changes were made. The images or other third party material in this article are included in the article's Creative Commons licence, unless indicated otherwise in a credit line to the material. If material is not included in the article's Creative Commons licence and your intended use is not permitted by statutory regulation or exceeds the permitted use, you will need to obtain permission directly from the copyright holder. To view a copy of this licence, visit http://creativecommons.org/licenses/by/4.0/.

\section{References}

Allen CD, Macalady AK, Chenchouni H, Bachelet D, McDowell N, Vennetier M, Cobb N (2010) A global overview of drought and heat-induced tree mortality reveals emerging climate change risks for forests. Forest Ecol Manag 259:660-684. https://doi.org/10.1016/j. foreco.2009.09.001

Allen KA, Lehsten V, Hale K, Bradshaw R (2016) Past and future drivers of an unmanaged carbon sink in European temperate forest. Ecosystems 19:545-554. https://doi.org/ 10.1007/s10021-015-9950-1

Anderegg WRL, Kane JM, Anderegg L (2012) Consequences of widespread tree Mortality triggered by drought and temperature stress. Nat Clim Chang 3:30-36. https://doi.org/ 10.1038/nclimate 1635

Bahn M, Reichstein M, Davidson EA, Grünzweig J, Jung M, Carbone MS, Epron D, Misson L, Nouvellon Y, Roupsard O, Savage K, Trumbore SE, Gimeno C, Curiel YJ, Tang J, Vargas R, Janssens IA (2010) Soil respiration at mean annual temperature predicts annual total across vegetation types and biomes. Biogeoscience 7:2147-2157. https://doi. org/10.5194/bg-7-2147-2010

Balasmeh OI, Karmaker T (2020) Effect of temperature and precipitation on the vegetation dynamics of high and moderate altitude natural forests in India. J Indian Soc Remote 48:121-144. https://doi.org/10.1007/s12524-01901065-8

Barr AG, Griffis TJ, Black TA, Lee X, Staebler RM, Fuentes JD, Morgenstern K (2002) Comparing the carbon budgets of boreal and temperate deciduous forest stands. Can J Forest Res 32:813-822. https://doi.org/10.1139/x01-131

Bartholy J, Pongrácz R, Gy G (2007) Regional climate change expected in Hungary for 2071-2100. Appl Ecol Env Res 5:1-17. https://doi.org/10.15666/aeer/0501_001017 
Batjes NH (1998) Mitigation of atmospheric $\mathrm{CO}_{2}$ concentrations by increased carbon sequestration in the soil. Biol Fert Soils 27:230-235. https://doi.org/10.1007/ s003740050425

Beni Á, Soki E, Lajtha K, Fekete I (2014) An optimized HPLC method for soil fungal biomass determination and its application to a detritus manipulation study. J Microbiol Methods 103:124-213. https://doi.org/10.1016/j.mimet. 2014.05.022

Beni Á, Lajtha K, Kozma J, Fekete I (2017) Application of a Stir Bar Sorptive Extraction sample preparation method with HPLC for soil fungal biomass determination in soils from a detrital manipulation study. J Microbiol Methods 136:1-5. https://doi.org/10.1016/j.mimet.2017.02.009

Berki I, Tar K (1991) Investigation of the precipitation series in the North Hungarian Mountains with respect to the oak decay. In: Proceeding of the international conference of mountainous meteorology, climatology and aerology of the lower layers of troposphere, Stará Lesna 36-42.

Berki I, Bidló A, Drüszler A, Eredics A, Gálos B, Mátyás C, Rasztovits E (2014) Afforestation for restoration of land and climate change mitigation. In: Climate change and restoration of degraded land. Colegio de Ingenieros de Montes 53-156.

Berthrong ST, Piñeiro G, Jobbágy EG, Jackson RB (2012) Soil $\mathrm{C}$ and $\mathrm{N}$ changes with afforestation of grasslands across gradients of precipitation and plantation age. Ecol Appl 22:76-86. https://doi.org/10.1890/10-2210.1

Błońska E, Lasota J, Piaszczyk W (2019) Carbon and nitrogen stock in deadwood biomass in natural temperate forest along a soil moisture gradient. Plant Biosyst. https://doi. org/10.1080/11263504.2019.1587538

Bond-Lamberty B, Thomson A (2010) Temperature-associated increases in the global soil respiration record. Nature 464:579-582. https://doi.org/10.1038/nature08930

Bond-Lamberty B, Bailey VL, Chen M, Gough CM, Vargas R (2018) Globally rising soil heterotrophic respiration over recent decades. Nature 560:80-83. https://doi.org/10.1038/ s41586-018-0358-x

Bowden RD, Deem L, Plante AF, Peltre C, Nadelhoffer K, Lajtha K (2014) Litter input controls on soil carbon in a temperate deciduous forest. Soil Sci Soc Am J 78:S66-S75. https://doi.org/10.2136/sssaj2013.09.0413nafsc

Brady NC, Weil RR (1999) The nature and properties of soils, 12th edn. Prentice Hall Publishers, London

Burke IC, Yonker CM, Parton WJ, Cole CV, Flach K, Schimel DS (1989) Texture, climate, and cultivation effects on soil organic matter content in US grassland soils. Soil Sci Soc Am J 53:800-805. https://doi.org/10.2136/sssaj1989. 03615995005300030029x

Buurman P, van Lagen B, Velthorst EJ (eds) (1996) Manual for soil and water analysis. Wageningen Agricultural University, Wageningen

Buurman P, van Lagen B, Piccolo A (2002) Increase in stability against thermal oxidation of soil humic substances as a result of self-association. Org Geochem 33:367-381. https://doi.org/10.1016/S0146-6380(01)00167-x

Canadell JG, Le Quere C, Raupach MR, Field CB, Buitenhuis ET, Ciais P, Marland G (2007) Contributions to accelerating atmospheric $\mathrm{CO}_{2}$ growth from economic activity, carbon intensity, and efficiency of natural sinks. Proc Natl
Acad Sci 104:18866-18870. https://doi.org/10.1073/pnas. 0702737104

Centeri C, Szalai Z, Jakab G, Barta K, Farsang A, Szabó S, Bíró Z (2015) Soil erodibility calculations based on different particle size distribution measurements. Hung Geo Bull 64:17-23. https://doi.org/10.15201/hungeobull.64.1.2

Chapin FSI, McFarland J, McGuire AD, Euskirchen ES, Ruess RW, Kielland K (2009) The changing global carbon cycle: linking plant-soil carbon dynamics to global consequences. J Ecol 97:840-850. https://doi.org/10.1111/j.1365-2745. 2009.01529.x

Chen H, Harmon ME, Griffiths RP, Hicks W (2000) Effects of temperature and moisture on carbon respired from decomposing woody roots. For Ecol Manag 138:51-64. https://doi.org/10.1016/S0378-1127(00)00411-4

Chen X, Zhang D, Liang G, Qiu Q, Liu J, Zhou G, Liu S, Chu G, Yan J (2016) Effects of precipitation on soil organic carbon fractions in three subtropical forests in southern China. J Plant Ecol 9:10-19. https://doi.org/10.1093/jpe/rtv027

Chen J, Elsgaard L, van Groenigen KJ, Olesen JE, Liang Z, Jiang Y, Lærke PE, Zhang Y, Luo Y, Hungate BA, Sinsabaugh RL, Jørgensen U (2020) Soil carbon loss with warming: New evidence from carbon degrading enzymes. Glob Change Biol 26:1944-1952. https://doi.org/10.1111/ gcb. 14986

Chichester FW, Chaison RF (1992) Analysis of carbon in calcareous soils using a two temperature dry combustion infrared instrumental procedure. Soil Sci 153:237-241. https://doi.org/10.1097/00010694-199203000-00007

Clark PU, Shakun JD, Marcott SA, Mix AC, Eby M, Kulp S, Plattner GK (2016) Consequences of twenty-first-century policy for multi-millennial climate and sea-level change. Nat Clim Change 6:360-369. https://doi.org/10.1038/ nclimate 2923

Cotrufo MF, Wallenstein MD, Boot CM, Denef K, Paul E (2013) The M icrobial E fficiency-M atrix $S$ tabilization (MEMS) framework integrates plant litter decomposition with soil organic matter stabilization: do labile plant inputs form stable soil organic matter? Glob Change Biol 19:988-995. https://doi.org/10.1111/gcb.12113

Dell' Abate MT, Benedetti A, Trinchera A, Dazzi C (2002) Humic substances along the profile of two Typic Haploxerert. Geoderma 107:281-296. https://doi.org/10.1016/ S0016-7061(01)00153-7

Dixon RK, Brown S, Houghton RA, Solomon AM, Trexler MC, Wisniewski J (1994) Carbon pool and flux of global forest ecosystems. Science 263:185-190. https://doi.org/10. 1126/science.263.5144.185

Domonkos P (2003) Recent precipitation trends in Hungary in the context of larger scale climatic change. Nat Hazards 29:255-271. https://doi.org/10.1023/A:1023690014955

Ellenber H (1988) Vegetation ecology of central Europe, 4th edn. Cambridge University Press, Cambridge, pp 71-138

Epstein HE, Burke IC, Lauenroth WK (2002) Regional patterns of decomposition and primary production rates in the U.S. Great Plains Ecol 83:320-327. https://doi.org/10.1890/ 0012-9658(2002)083[0320:RPODAP]2.0.CO;2

Fekete I, Varga C, Halász J, Krakomperger Z, Krausz E (2008) Study of litter decomposition intensity in litter manipulative trials in Síkfokút Cambisols. Cereal Res Commun 36:1779-1782 
Fekete I, Kotroczó Z, Varga C, Vares Z, Tóth JA (2011) The effects of detritus inputs on soil organic matter content and carbon-dioxide emission in a Central European deciduous forest. Acta Silv Lign Hung 7:87-96

Fekete I, Kotroczó Z, Varga C, Nagy PT, Várbíró G, Bowden RD, Tóth JA, Lajtha K (2014) Alterations in forest detritus inputs influence soil carbon concentration and soil respiration in a Central-European deciduous forest. Soil Biol Biochem 74:106-114. https://doi.org/10.1016/j.soilbio. 2014.03.006

Fekete I, Varga C, Biró B, Tóth JA, Várbíró G, Lajtha K, Szabó G, Kotroczó Z (2016) The effects of litter production and litter depth on soil microclimate in a central European deciduous forest. Plant Soil 398:291-300. https://doi.org/ 10.1007/s11104-015-2664-5

Fekete I, Lajtha K, Kotroczó Z, Várbíró G, Varga C, Tóth JA, Demeter I, Veperdi G, Berki I (2017) Long term effects of climate change on carbon storage and tree species composition in a dry deciduous forest. Glob Change Biol 23:3154-3168. https://doi.org/10.1111/gcb.13669

Fensham RJ, Holman JE (1999) Temporal and spatial patterns in drought-related tree dieback in Australian savanna. J Appl Ecol 36:1035-1050

Field CB, Raupach MR (eds) (2004) The global carbon cycle: integrating humans, climate, and the natural world. Island Press, Washington, p 529

Fontaine S, Barot S, Barré P, Bdioui N, Mary B, Rumpel C (2007) Stability of organic carbon in deep soil layers controlled by fresh carbon supply. Nature 450:277-280. https://doi.org/10.1038/nature06275

Francioso O, Montecchio D, Gioacchini P, Ciavatta C (2005) Thermal analysis (TG-DTA) and isotopic characterization $\left({ }^{13} \mathrm{C}-{ }^{15} \mathrm{~N}\right)$ of humic acids from different origins. Appl Geochem 20:537-544. https://doi.org/10.1016/j. apgeochem.2004.10.003

Galos B, Goettel H, Haensler A, Preuschmann S, Matyas C, Jacob D (2009) Do forest cover changes have any feedback on temperature and precipitation extremes over Hungary? Geophysical Res Abstr 11:EGU2009-7687-1

Gaudinski JB, Trumbore SE, Davidson E, Zheng S (2000) Soil carbon cycling in a temperate forest: radiocarbon-based estimates of residence times, sequestration rates and partitioning of fluxes. Biogeochemistry 51:33-69. https://doi. org/10.1023/A:1006301010014

Gestel N, Shi Z, Van Groenigen KJ, Osenberg CW, Andresen LC, Dukes JS, Hungate BA (2018) Predicting soil carbon loss with warming. Nature 554(7693):E4-E5. https://doi. org/10.1038/nature25745

Jenny H (1980) The soil resource. Springer, NewYork

Keeling CD, Chin JFS, Whorf TP (1996) Increased activity of northern vegetation inferred from atmospheric $\mathrm{CO}_{2}$ observations. Nature 382:146-149. https://doi.org/10. $1038 / 382146 \mathrm{a} 0$

Kocsis T, Biró B, Ulmer Á, Szántó M, Kotroczó Z (2018) Timelapse effect of ancient plant coal biochar on some soil agrochemical parameters and soil characteristics. Environ Sci Pollut Res 25:990-999. https://doi.org/10.1007/ s11356-017-8707-0

Kotroczó Z, Fekete I, Toth JA, Tothmeresz B, Balazsy S (2008) Effect of leaf-and root-litter manipulation for carbon- dioxide efflux in forest soil. Cereal Res Commun 36:663-666. https://doi.org/10.1556/CRC.36.2008

Kotroczó Z, Juhos K, Biró B, Kocsis T, Pabar SA, Varga C, Fekete I (2020) Effect of detritus manipulation on different organic matter decompositions in temperate deciduous forest soils. Forests 11:675. https://doi.org/10.3390/ f11060675

Kramer MG, Chadwick OA (2018) Climate-driven thresholds in reactive mineral retention of soil carbon at the global scale. Nat Clim Change 8:1104-1108. https://doi.org/10.1038/ s41558-018-0341-4

Kuzyakov Y (2010) Priming effects: Interactions between living and dead organic matter. Soil Biol Biochem 42:1363-1371. https://doi.org/10.1016/j.soilbio.2010.04. 003

Li J, Nie M, Pendall E, Reich PB, Pei J, Noh NJ, Zhu T, Li B, Fang C (2020) Biogeographic variation in temperature sensitivity of decomposition in forest soils. Glob Chang Biol 26:1873-1885. https://doi.org/10.1111/gcb.14838

Luyssaert S, Ciais P, Piao SL, Schulze ED, Jung M, Zaehle S, Schelhaas MJ, Reichstein M, Churkina G, Papale D, Abril G, Beer C, Grace J, Loustau D, Matteucci G, Magnani F, Nabuurs GJ, Verbeeck H, Sulkava M, Van der Werf GR, Janssens IA, Members of the Carboeurope-IP Synthesis Team (2010) The European carbon balance. Part 3: forests. Glob Chang Biol 16:1429-1450. https://doi.org/10.1111/j. 1365-2486.2009.02056.x

Makó A, Tóth G, Weynants M, Rajkai K, Hermann T, Tóth B (2017) Pedotransfer functions for converting laser diffraction particle size data to conventional values. Eur J Soil Sci 68:769-782. https://doi.org/10.1111/ejss.12456

Mátyás C, Berki I, Bidló A, Csóka G, Czimber K, Führer E, Gálos B, Gribovszki Z, Illés G, Hirka A (2018) Sustainability of forest cover under climate change on the temperate-continental xeric limits. Forests 9(8):489. https:// doi.org/10.3390/f9080489

Ma L, Shen C, Lou D, Fu S, Guan D (2017) Ecosystem carbon storage in forest fragments of differing patch size. Sci Rep 7:13173. https://doi.org/10.1038/s41598-017-13598-4

McGarvey JC, Thompson JR, Epstein HE, Shugart HH Jr (2015) Carbon storage in old-growth forests of the Mid-Atlantic: toward better understanding the eastern forest carbon sink. Ecology 96:311-317. https://doi.org/10.1890/14-1154.1

Meier IC, Leuschner C (2010) Variation of soil and biomass carbon pools in beech forests across a precipitation gradient. Glob Change Biol 16:1035-1045. https://doi.org/10. 1111/j.1365-2486.2009.02074.x

Mohan JE, Cox RM, Iverson LR (2009) Composition and carbon dynamics of forests in northeastern North America in a future, warmer world. Can J For Res 39:213-230. https:// doi.org/10.1139/X08-185

Montecchio D, Francioso O, Carletti P, Pizzeghello D, Chersich S, Previtali F, Nardi S (2006) Thermal analysis (TG-DTA) and drift spectroscopy applied to investigate the evolution of humic acids in forest soil at different vegetation stages. J Therm Anal Calorim 83:393-399. https://doi.org/10. 1007/s10973-005-7292-5

Muggeo VM (2017) Interval estimation for the breakpoint in segmented regression: a smoothed score-based approach. Aust Nz J Stat 59:311-322. https://doi.org/10.1111/anzs. 12200 
Nepstad DC, Tohver IM, Ray D, Moutinho P, Cardinot G (2007) Mortality of large trees and lianas following experimental drought in an Amazon forest. Ecology 88:2259-2269. https://doi.org/10.1890/06-1046.1

O'Brien SL, Jastrow JD, Grimley DA, Gonzalez-Meler MA (2010) Moisture and vegetation controls on decadal-scale accrual of soil organic carbon and total nitrogen in restored grasslands. Glob Change Biol 16:2573-2588. https://doi. org/10.1111/j.1365-2486.2009.02114.x

Oertel C, Matschullat J, Zurba K, Zimmermann F, Erasmi S (2016) Greenhouse gas emissions from soils-a review. Geochemistry 76:327-352. https://doi.org/10.1016/j. chemer.2016.04.002

Peltre C, Fernández JM, Craine JM, Plante AF (2013) Relationships between biological and thermal indices of soil organic matter stability differ with soil organic carbon level. Soil Sci Soc Am J 77:2020-2028. https://doi.org/10. 2136/sssaj2013.02.0081

Rasmussen C, Throckmorton H, Liles G, Heckman K, Meding S, Horwath WR (2018) Controls on soil organic carbon partitioning and stabilization in the California Sierra Nevada. Soil Syst 2:41. https://doi.org/10.3390/ soilsystems2030041

Rasse DP, Rumpel C, Dignac MF (2005) Is soil carbon mostly root carbon? Mechanisms for a specific stabilization. Plant Soil 269:341-356. https://doi.org/10.1007/s11104-0040907-y

Rovira P, Kurz-Besson C, Couteaux MM, Vallejo VR (2008) Changes in litter properties during decomposition: a study by differential thermogravimetry and scanning calorimetry. Soil Biol Biochem 40:172-185. https://doi.org/10. 1016/j.soilbio.2007.07.021

Rowley MC, Grand S, Verrecchia ÉP (2018) Calcium-mediated stabilisation of soil organic carbon. Biogeochemistry 137:27-49. https://doi.org/10.1007/s10533-017-0410-1

Salamon-Albert É, Lőrincz P, Pauler G, Bartha D, Horváth F (2016) Drought Stress distribution responses of continental beech forests at their xeric edge in central Europe. Forests 7:298. https://doi.org/10.3390/f7120298

Samaniego L, Thober S, Kumar R, Wanders N, Rakovec O, Pan M, Zink M, Sheffield J, Wood EF, Marx A (2018) Anthropogenic warming exacerbates European soil moisture droughts. Nat Clim Change 8:421-426. https://doi.org/ 10.1038/s41558-018-0138-5

Sándor Z, Tállai M, Kincses I, László Z, Kátai J, Vágó I (2020) Effect of various soil cultivation methods on some microbial soil properties. DRC Sustain Fut 1:14-20. https://doi. org/10.37281/drcsf/1.1.3

Santonja M, Fernandez C, Gauquelin T, Baldy V (2015) Climate change effects on litter decomposition: intensive drought leads to a strong decrease of litter mixture interactions. Plant Soil 393:69-82. https://doi.org/10.1007/s11104-0152471-z

Schlesinger WH (1997) Biogeochemistry. An analysis of global change, 2nd edn. Academic Press, San Diego

Sierra C, Müller M, Trumbore SE (2014) Modeling radiocarbon dynamics in soils: soil R version 1.1. Geosci Model Dev 7:1919-1931. https://doi.org/10.5194/gmd-7-1919-2014

Sierra CA, Hoyt AM, He Y, Trumbore SE (2018) Soil organic matter persistence as a stochastic process: age and transit time distributions of carbon in soils. Global Biogeochem
Cycles 32:1574-1588. https://doi.org/10.1029/ 2018GB005950

Singh M, Sarkar B, Sarkar S, Churchman J, Bolan N, Mandal S, Menon M, Purakayastha TJ, Beerling DJ (2018) Chapter two-stabilization of soil organic carbon as influenced by clay mineralogy. Adv Agron 148:33-84. https://doi.org/ 10.1016/bs.agron.2017.11.001

Smith P, Fang C (2010) Carbon cycle: a warm response by soils. Nature 464:499-500. https://doi.org/10.1038/464499a

Soetaert K, Petzoldt T (2010) Inverse modelling, sensitivity and Monte Carlo analysis in R using Package FME. J Stat Softw 33:1-28. https://doi.org/10.18637/jss.v033.i03

Steinhof A, Altenburg M, Machts H (2017) Sample preparation at the Jena $\mathrm{C}^{14}$ Laboratory. In: Proceedings of the 22nd international radiocarbon conference, vol. 59, pp 815-830 (Special Issue)

Sun W, Liu X (2020) Review on carbon storage estimation of forest ecosystem and applications in China. For Ecosyst 7:4. https://doi.org/10.1186/s40663-019-0210-2

Szili-Kovács T, Kátai J, Takács T (2011) Mikrobiológiai indikátorok alkalmazása a talajminőség értékelésében. Agrokem Talajtan 60:273-286. https://doi.org/10.1556/ Agrokem.60.2011.1.20

Tefs C, Gleixner G (2012) Importance of root derived carbon for soil organic matter storage in a temperate old-growth beech forest-evidence from $\mathrm{C}, \mathrm{N}$ and $\mathrm{C}^{14}$ content. For Ecol Manag 263:131-137. https://doi.org/10.1016/j.foreco. 2011.09.010

Thalmann A (1968) Dehydrogenase activity. In: Alef K, Nannipieri P (eds.) Methods in applied soil microbiology and biochemistry. Academic Press Ltd, pp 228-230

Tian H, Lu C, Ciais P et al (2016) The terrestrial biosphere as a net source of greenhouse gases to the atmosphere. Nature 531:225-228. https://doi.org/10.1038/nature16946

Tomiczek C (1993) Oak decline in Austria and Europe. J Arboricult 19:71-73

Tóth JA, Nagy PT, Krakomperger Z, Veres Z, Kotroczó Z, Kincses S, Fekete I, Papp M, Lajtha K (2011) Effect of litter fall on soil nutrient content and $\mathrm{pH}$, and its consequences in view of climate change (Síkfökút DIRT Project). Acta SilvLign Hung 7:75-86

Trevors JT (1984) Dehydrogenase activity in soil: a comparison between the INT and TTC assay. Soil Biol Biochem 16:673-674. https://doi.org/10.1016/0038-0717(84) 90090-7

Trumbore S (2009) Radiocarbon and soil carbon dynamics. Annu Rev Earth Planet Sci 37:47-66. https://doi.org/10. 1146/annurev.earth.36.031207.124300

Trumbore SE, Sierra C, Pries CEH (2016) Radiocarbon nomenclature, theory, models, and interpretation: measuring age, determining cycling rates, and tracing source pools. In: Schuur EAG, Druffel ERM, Trumbore SE (eds) Radiocarbon and global change. Springer, Cham, pp 45-82

Urban J, Čermák J, Ceulemans R (2015) Above- and belowground biomass, surface and volume, and stored water in a mature Scots pine stand. Eur J For Res 134:61-74

Uzarowicz Ł, Wolińska A, Błońska E, Szafranek-Nakonieczna A, Kuźniar A, Słodczyk Z, Kwasowski W (2020) Technogenic soils (Technosols) developed from mine spoils containing Fe sulphides: Microbiological activity as an indicator of soil development following land 
reclamation. Appl Soil Ecol 156:103699. https://doi.org/ 10.1016/j.apsoil.2020.103699

Van Mantgem PJ, Stephenson NL, Byrne JC, Daniels LD, Franklin JF, Fulé PZ, Harmon ME, Larson AJ, Smith JM, Taylor AH, Veblen TT (2009) Widespread increase of tree mortality rates in the western United States. Science 323:521-524. https://doi.org/10.1126/science. 1165000

Veres Z, Kotroczó Z, Magyaros K, Tóth JA, Tóthmérész B (2013) Dehydrogenase activity in a litter manipulation experiment in temperate forest soil. Acta Silv Lign Hung 9:25-33. https://doi.org/10.2478/aslh-2013-0002

von Lützow M, Kögel-Knabner I (2009) Temperature sensitivity of soil organic matter decomposition-what do we know? Biol Fert Soils 46:1-15. https://doi.org/10.1007/ s00374-009-0413-8

Wei W, Weile C, Shaopeng W (2010) Forest soil respiration and its heterotrophic and autotrophic components: global patterns and responses to temperature and precipitation. Soil Biol Biochem 42:1236-1244. https://doi.org/10.1016/j. soilbio.2010.04.013

Wiesmeier M, Hübner R, Spörlein P, Geu U, Hangen E, Reischl A, Schilling B, von Lützow M, Kögel-Knabner I (2014) Carbon sequestration potential of soil in southeast
Germany derived from stable soil organic carbon saturation. Glob Change Biol 20:653-665. https://doi.org/10. $1111 / \mathrm{gcb} .12384$

Zhou G, Wang Y, Wang S (2002) Responses of grassland ecosystems to precipitation and land use along the Northeast China Transect. J Veg Sci 13:361-368. https://doi.org/ 10.1111/j.1654-1103.2002.tb02060.x

Zhou GY, Guan LL, Wei XH, Tang X, Liu S, Liu J, Zhang D, Yan J (2008) Factors influencing leaf litter decomposition: an intersite decomposition experiment across China. Plant Soil 311:61-72. https://doi.org/10.1007/s11104-008-96585

Zhou WJ, Sha LQ, Schaefer DA, Zhang YP, Song QH, Tan ZH, Guan HL (2015) Direct effects of litter decomposition on soil dissolved organic carbon and nitrogen in a tropical rain forest. Soil Biol Biochem 81:255-258. https://doi.org/10. 1016/j.soilbio.2014.11.019

Publisher's Note Springer Nature remains neutral with regard to jurisdictional claims in published maps and institutional affiliations. 